\title{
THE "SPANISH" ORIGINS OF INTERNATIONAL HUMAN RIGHTS LAW: A HISTORIOGRAPHICAL REVIEW
}

\author{
RP Boast*
}

\begin{abstract}
This article critically reviews the claim that the Spanish jurist-theologians Francisco de Vitoria and Bartolomé de las Casas, and their successors, were pioneers of human rights theory and of the law relating to the rights of indigenous peoples. The article seeks to clarify the literature relating to these claims by dividing it into various categories and analysing each in turn. A principal aim of the article is to convey the sheer diversity and scale of the various competing historiographies and the extent to which they stand in contrast to each other. By way of conclusion, there is a discussion of those parts of the debate which are of greatest relevance and resonance for a jurisdiction such as New Zealand, where questions about the origins and nature of indigenous rights law are not merely a matter of theoretical interest, but also of great practical relevance.
\end{abstract}

\section{INTRODUCTION}

In this article I will traverse some of the main lines of debate over the origins of human rights law, particularly the law relating to the rights of indigenous peoples within metropolitan States. The origins of the legal edifice in existence today are claimed by many, especially scholars within the naturalist camp, to originate with a number of 16 th century "Spanish" writers and teachers. ${ }^{1}$ Critics

* Barrister; Professor of Law, Victoria University of Wellington. I would like to thank the anonymous reviewer who commented in detail on an earlier draft of this article and who made a number of helpful suggestions. Because of other commitments and for other reasons I have not had an opportunity to incorporate all of these suggestions into the current text. This article is written as an introductory survey for those curious about the "Spanish" school and interested in exploring current historiographies. (Obviously it is also written from an antipodean perspective and is here published in an antipodean law journal.)

1 One reason for placing the word "Spanish" in inverted commas is that the political formation we call "Spain" was still in the process of construction - a process that arguably has never been completed - in the 16th century; the reign of Ferdinand and Isabella was in fact a personal union of the separate Crowns of Aragon and Castile. Moreover, during the reign of Charles (Carlos) V (1500-1558, King of Spain 15161556, Holy Roman Emperor 1519-1558), the empire was part of a European wide Habsburg political entity governed from Brussels as much as it was from Spain; Charles, son of Juana of Castile-Aragon and Philip of Habsburg, grew up in the Burgundian culture of Flanders and his first language was in fact French. Las 
of this same edifice, who see it as racist and disempowering, also make the same assumption - as will be seen. The key historical figures are two Spanish Renaissance intellectuals, Francisco de Vítoria and Bartolomé de las Casas, although other scholars and writers are brought within the same tradition, including Melchior Cano, Dominic de Soto, Pedro de Sotomayor and Francisco Suárez. ${ }^{2}$ (The latter figures, Suárez aside, all of them important in their own right, tend to be much less discussed.) Some naturalist scholars see Vítoria as pioneering a natural law approach to international law, in contrast to a "positivist" approach, which sees international law as arising out of the practices, usages and customs of States, treaties and decisions of international and domestic courts. ${ }^{3}$ But some claims go much further than this. For instance, Vítoria has been said to be a theorist of human rights and even a "democrat", a Thomas Jefferson or a Thomas Paine before his time, certainly a surprising claim to make on behalf of a 16th century Dominican theologian. We have been told, for example, that in Vítoria: ${ }^{4}$

... we find the first virtually complete enumeration of human rights and principles of democratic government and law, both on a national and international level, long before the American Declaration of Independence and Thomas Paine's Rights of Man.

Vítoria has even been described by a writer within this tradition as "the original philosopher of rights". 5 There is thus an established body of writing that confidently traces human rights theory to a

Casas felt that he was assured of a much better hearing from Charles V's cosmopolitan officials, who were often Flemish and Italian, than he was from the Spanish government.

2 See for example John P Doyle "Francisco Suárez: On Preaching the Gospel to People like the American Indians" (1991-1992) 15 Fordham Int'l LJ 879 at 884-885. As Doyle admits, however, Suárez barely mentions the American Indians anywhere in his writings: ibid, at 884-885.

3 Thomas C Donohue SJ "Vitoria's Universalism and the World Rule of Law" (1960) 6 Cath Law 200; Ramón Hernández OP "The Internationalization of Francisco de Vitoria and Domingo de Soto" (1991-1992) 15 Fordham Int'l LJ 1031; Joseph M de Torre "The Roots of International Law and the Teachings of Francisco de Vitoria as Foundations for Transcendent Human Rights and International Peace" (2004) 2 Ave Maria Law Review 123.

4 Torre, above n 3 , at 139.

5 Marcelo Sánchez-Sorondo "Vitoria: The Original Philosopher of Rights" in Kevin White (ed) Hispanic Philosophy in the Age of Discovery (Catholic University of America Press, Washington (DC), 1997) 59. Sánchez-Sorondo's vision is encapsulated in the last paragraph of his essay (ibid, at 68):

We hope that the message of Vitoria, the five hundredth anniversary of whose birth was commemorated in 1992, might be a beam of living light for the peoples of America and of the world in this decisive moment at the end of the millennium when its most transcendental event is being commemorated: the discovery of America, which is also the discovery of the natural sacredness of man as man, the image of God.

I have immense trouble in seeing how the discovery of America was "also the discovery of the natural sacredness of man", a personal shortcoming no doubt. By way of rejoinder, the rather different perspective of a prominent Caribbean scholar can be noted: see Salvio Torres-Saillant An Intellectual History of the Caribbean (Palgrave Macmillan, New York, 2006) at 28: 
key group of thinkers and writers in Renaissance Spain. This article is primarily written for those who are intrigued by this claim, but who at the same time are interested in testing it against the historiography relating to European colonial expansion generally and that relating to the Spanish colonial empire in particular. The focus of this article is theoretical and, especially, historiographical. However, it is also written within the framework of the inescapable reality that issues of indigenous sovereignty and the investigation and resolution of indigenous historical claims have a particular relevance and urgency in this part of the world that scholars writing about Vítoria and Las Casas in other countries, especially metropolitan States like Spain, France and Britain, do not have to confront in the same way. It seems to me that questions relating to the foundations of the edifice of western law concerning the rights of indigenous peoples are peculiarly important in those societies which are confronted with the necessity of having to deal with the historical legacies of European colonialism as a matter of practical law and politics virtually on a daily basis. Moreover, it might be the case that an antipodean experience can bring a distinctive contribution of its own to the international marketplace of ideas about historiography, rights and the legacy of colonialism. ${ }^{6}$

Although some of the claims made by many naturalist scholars regarding the legacy of Vítoria and others seem to be certainly much too significant, this article is not written as a critique of Vítoria or of natural law human rights theory, but principally with the more modest aspiration of analysing the various discourses that have developed concerning the legacy of what for the purposes of discussion we can call the "Spanish school". While I have no quarrel with naturalism as such, I hope at least to show that some of the more sweeping claims that have been made from time to time should not be accepted uncritically. I hope to connect up the debates and discussions amongst legal scholars, who are not always familiar with the literature relating to Spanish colonial expansion, with the wider historiography relating to the Spanish colonial empire. Such a task must of course be embarked on with all due humility, given the complexity of the subject-matter and the sheer scale of the literature. Nevertheless, it can validly be asserted that much of the writing about the Spanish school is marked by what seems to be a highly tendentious, uncritical and even naive approach to the realities of Spanish imperialism. Some scholars indeed feel the need to preface their discussions of the ideas of the Spanish theorists with a short lecture reminding the reader of the power, greatness and glory of Renaissance Spain. ${ }^{7}$ It may, however, come as a surprise to those who believe in the

It would seem better advised to approach this subject by focusing on the survival and resilience of the Antillean person, the way she has emerged from a checkered history of glory, disappointment, aggression, hope, betrayal and joy since 1492 when heavily armed invaders came in their ships to disembowel Tainos, rape Tainas, burn religious temples, and generally trample upon the human dignity of the native population.

6 The present writer's interest in the field has grown out of many years of engagement as a practising research historian and lawyer working with indigenous people in litigation relating to, and the practical settlement of, indigenous historical claims in New Zealand.

7 See for example Doyle, above n 2, at 879: 
central importance of Vítoria that many historians of Spanish colonial expansion see him as a minor figure. One important school of Latin American historiography, as will be seen, has chosen to go out of its way to ignore the debates over empire and law in metropolitan Spain completely.

\section{VÍTORIA, LAS CASAS ET AL}

The key figures who can plausibly be put forward as contenders for a "Spanish" origin of human rights theory and practice are thus Vítoria and Las Casas, both members of the Dominican order founded originally by St Dominic in the 13th century to combat heresy in southern France. To jurists it is Vítoria who is seen as the key figure, while historians of the Spanish colonial world tend to treat him as a figure of passing interest and concentrate much more on the protean figure of Las Casas. Strangely, Vítoria, the professor and scholar, seems to be much congenial to human rights and international law specialists than the furiously activist Las Casas, beyond any doubt the historically more important personality and by far the more prolific writer (Vítoria wrote nothing for publication, as far as is known, whereas Las Casas' vast corpus is still being published today). ${ }^{8}$ Of

[In the 16th century] [i]n just about every area, Spain led the way ... [i]n ecclesiastical politics, in theology, and in spirituality, Spanish influence was clear before, during, and after the Council of Trent. In broader fields of university education, humanistic learning, literature, and art, Spaniards excelled.

Salamanca was, he adds, "the finest university in the world" (ibid, at 881). In fact, compared with Italy, Spain was backward in "humanistic learning" and while Spanish political importance can hardly be denied, culturally Spain lagged far behind Italy and France, and whether Salamanca was "the finest university in the world" - compared, say, with the University of Padua, at which Galileo taught and which lay within the territories of the Republic of Venice, or the University of Paris, the centre of theological learning in Europe, is a very debatable claim. The greatest humanist scholar of the age, Erasmus, was invited to Spain but declined to go there, regarding Spain as a backwater. Many writers who eulogise the "Spanish school" feel obliged to preface their discussions of the jurists with a paean to the glory and power of Renaissance Spain, perhaps to counter the lingering residue of the "Black Legend" assumed to linger in the minds of Anglophone readers. See Henry Kamen Spain's Road to Empire: The Making of a World Power 1492-1763 (Penguin, London, 2002) for a refreshingly unsentimental and clear recent analysis of the Spanish colonial empire - which, amongst other things, queries the extent to which the empire was in fact actually "Spanish".

8 What survives of Vítoria's ideas are contained in notes made by students of his lectures on Aquinas and Peter Lombard and of his relectiones ("re-readings"), formal lectures given on special occasions which dealt with current issues of the day. The lectures and the notes were, as was standard, in Latin. De Indis ("On the Indies" or "On the Affairs of the Indies") was written in 1537-1538, that is well after the conquest of Mexico and while the conquest of Peru was still going on. An accessible modern English translation is Anthony Pagden and Jeremy Lawrance (eds) Vitoria: Political Writings (Cambridge University Press, Cambridge, 1991) [Vítoria, Pagden and Lawrance] (This edition is relied on in this article). His most-cited work is De Indis; the other surviving texts deal with the Civil Power, the Power of the Church, Law, Dietary Laws and the Law of War. That a figure as compelling and as influential as Vitoria should publish nothing in his own lifetime is not as suprising as it might seem: 16th century civilisation was an oral and rhetorical culture in many respects. John O'Malley has decribed the practice of the early Jesuits of giving sacred lectures, a distinct activity from preaching sermons, a practice carried out on a very large scale and with significant impacts - but, as with the relectiones, the lectures were not written down or afterwards published and what is known of them comes from notes taken down by those present: see John W O'Malley The First Jesuits (Harvard University Press, Cambridge, 1993) at 105-110. The Lascasian corpus by contrast is vast; 
the two it was Las Casas who was by far the more astringent, indeed savage, critic of Spanish behaviour in the New World. The very ferocity of Las Casas' criticism is problematic for those who wish to eulogise the "Spanish" contribution to human rights theory, given that Las Casas simultaneously demonstrates as well as undercuts claims that the origins of human rights law and theory originate in Renaissance Spain. Some of the historiography reviewed here focuses more particularly on Vítoria and his successors, some of it more particularly on Las Casas. Jurists and legal historians are more interested in Vítoria and neglect Las Casas; historians of the Spanish empire tend to be less interested in Vítoria and more focused on Las Casas; other writers, as will be seen, resolutely ignore both of them.

Francisco de Vítoria is a far more shadowy character than Las Casas in the sense that very little is known about his life and career. (Since so little is known, much of what has been said about him is for that reason alone very suspect.) Even his date of birth is a mystery, although that is not unusual in the circumstances of 15th and 16th century Spanish history, estimates ranging from 1473 to $1486 .{ }^{9}$ "Vítoria" is simply the name of a town in the Basque country. It is known that Francisco studied theology at the Sorbonne in Paris, at the time the unrivalled centre for the study and teaching of theology and philosophy in Europe and a bastion of Thomism and Aristotelianism. Arriving in Paris around 1506, Francisco was based at the Dominican college at the Sorbonne, where he studied and then taught for 18 years. He afterwards returned to Spain and may have taught at Valladolid before he was elected - by the students - to the prima chair of theology at Salamanca, certainly the greatest and most prestigious of the Spanish universities. Vítoria was a theology professor and did not teach either civil or canon law. He became eminent and respected in Spain. His teachings on the Crown's rights to the Indies on one occasion incurred the displeasure of Emperor Charles V, who did not want to see matters of this kind debated in the universities of Castile without his permission. ${ }^{10}$ On the other hand, the Crown also sought Vítoria's advice on legal questions relating to the conversion of the indigenous peoples of New Spain, ${ }^{11}$ and in 1545 the Emperor and Prince

his most widely read work is his Brevísima relación de la destrucción de las Indias (Seville, 1552), which was soon published all over Europe; there is a Penguin classics edition translated by Nigel Griffin with an introduction by Anthony Pagden: A Short Account of the Destruction of the Indies (Penguin, London, 1992). The Brevisima relación was one of no less than nine treatises that Las Casas published from 1552-1553 alone. The nine treatises were republished in an edited facsimile edition in Mexico in 1965: see Lewis Hanke and Manuel Giménez Fernández (eds) Tratados de Fray Bartolomé de las Casas (Fondo de Cultura Económica, México, 1965) 2 vols.

9 James Brown Scott The Spanish Origin of International Law: Francisco de Vitoria and his Law of Nations (Clarendon Press and Humphrey Milford, London, 1934) at 70 [The Spanish Origin].

10 Ibid, at 84. See the letter of Carlos V.

11 Ibid, at 85-86. The key documents are three letters signed by the King of 31 January 1539, 18 April 1539 and 31 March 1541. The first and the third of these are requests for legal opinions, the first "regarding a matter then before the Council of the Indies on certain doubts as to the instruction and conversion of the natives in New Spain" and the third a similar request particularly with reference to the baptism of the 
Philip requested that he travel to Italy to represent the Spanish government at the Council of Trent (Vítoria declined on the grounds of age and poor health). ${ }^{12}$ Vítoria died in 1546 . The facts, such as there are, do not add up to a very close relationship between the Crown and Vítoria, who seems to have been regarded as an esteemed and expert academic of unquestionable Catholic orthodoxy. Nor, on the other hand, is there anything to suggest that he was engaged in a sustained polemic and attack on royal policy. Vítoria was able to teach freely and say what he pleased, and apparently led a quiet professorial sort of life. He established a solid tradition of a particular way of teaching and argumentation and certainly created a "school" in the sense that his students and then their students achieved European-wide prominence in their turn.

Las Casas, the other key figure, led a radically different life to that of Vítoria, one that was anything but professorial, and unlike Vítoria, who never crossed the Atlantic, Las Casas knew the Spanish American colonies well and was in a constant state of movement between the Caribbean, South America, Mexico and metropolitan Spain. ${ }^{13}$ Born in Seville in 1474, Las Casas became both a critic of government policy and a frequenter of the corridors of power. He led an amazingly energetic and productive - and very long - life. Again, he is unlike Vítoria in that we know a great deal about him. He wrote a colossal amount, was involved in a range of ambitious projects and was constantly on the move between Spain and the New World. He is also the subject of a substantial literature. ${ }^{14}$ Like Vítoria, he was a Dominican, but he joined the order later in life after having spent the early part of his life living as a settler and encomendero - that is, a holder of a right of tribute from indigenous communities - in the Caribbean. He saw the horrors of the conquest of Cuba at first hand and it was this searing experience which led to his decision to renounce his encomienda (grant) and devote his life to the cause of the Indian peoples of the Americas. Although an activist

Indians. The second was merely a letter forwarding a request from the Bishop of Mexico that Vítoria select some of his students as missionaries to be sent out to New Spain.

12 Ibid, at 86-87, where the King's letter and Vítoria's very courteous reply are reprinted.

13 The doyen of scholarship on Las Casas is Manuel Giménez Fernández (1896-1968); Giménez Fernández was of liberal Catholic leanings, and as well as being Professor of Canon Law at the University of Seville served as Minister of Agriculture under the Spanish Republic and later become an opponent of Franco's regime (all this is illustrative to some extent of the politicisation of Lascasian studies in Spain). For an accessible summation of his views, See Manuel Giménez Fernández "Fray Bartolomé de Las Casas: A Biographical Sketch" in Juan Friede and Benjamin Keen (eds) Bartolomé de Las Casas in History: Toward an Understanding of the Man and his Work (Northern Illinois University Press, De Kalb, 1971) 67.

14 For some key studies, see Gustavo Gutiérrez Las Casas: In Search of the Poor of Jesus Christ (Orbis, Maryknoll, New York, 1993). Gutiérrez is an important Latin American liberation theologian. See also Benjamin Keen "Gustavo Gutierrez. Las Casas: In Search of the Poor of Jesus Christ" (1995) 100 American Historical Review 617; Lewis Hanke All Mankind is One: A Study of the Disputation between Bartolomé de Las Casas and Juan Ginés de Sepúlveda on the Religious and Intellectual Capacity of the American Indians (Northern Illinois University Press, De Kalb, 1974). 
and controversialist, Las Casas was also a scholar and theologian of great weight and significance in his in own right, fully the equivalent of Vítoria in the eyes of some historians.

Las Casas is a controversial figure, particularly in the Hispanic world, far more so than Vítoria. To many he is a hero, a defender of the Indians, a man ahead of his time. To others, however, he is someone who was carried away by his own enthusiasm into distorting the truth. He was the founding father not so much of Indian rights, but rather of the "Black Legend", or la "Leyenda Negra", which sees Spain's role in the New World as especially coercive, cruel and oppressive. Most Spanish historians, conservative or not, see the black legend as a myth, and many AngloAmerican scholars would not disagree; but there are those, as will be seen, who regard the leyenda negra as essentially right as to the fundamentals. While admiration of Vítoria has remained consistently high, Las Casas' star has risen and fallen over the years; given the current popularity of indigenous causes it is certainly in the ascendant at present, and has been for some time. Las Casas has been an inspiration to many Latin Americans. Simon Bolívar, the great liberator, was certainly one admirer, and the contemporary Peruvian liberation theologian Gustavo Gutiérrez is another. Conservative Spanish and Latin American writers of the 1930s and 1940s, however, writing in the shadow of the ideological struggle epitomised by the Spanish Civil War, tended to denigrate Las Casas as a misguided zealot who unfairly and even unpatriotically blackened Spain's good name. ${ }^{15}$ More recently, a new revisionist critique of Las Casas has started to emerge, seeking to deflate his reputation as a defender of the Indians and suggesting that notwithstanding his criticism of the colonists he was nevertheless an active agent of Spanish imperialism, differing from the conquistadores and Crown officials only in his dislike of violence. ${ }^{16}$ In terms of his intellectual leanings and importance, Las Casas is also controversial, some seeing him simply as an activist with no coherent intellectual position while others see him as a consistent Thomist; yet, others see him as primarily a jurist who was influenced by and who developed medieval legal ideas. ${ }^{17}$ Also, Vítoria and Las Casas should not be simply bracketed together in terms of the content of their ideas. They

15 See the Spanish historian Ramón Menéndez Pidal El padre Las Casas: Su doble personalidad (EspasaCalpe, Madrid, 1963). Ramón Menéndez Pidal describes Las Casas as antichristian, as a vehement exaggerator, prone to presumptuous vanity and so on. See also Lewis Hanke "More Heat and Some Light on the Spanish Struggle for Justice in the Conquest of America" (1964) 64 Hispanic American Historical Review 293; Benjamin Keen "Approaches to Las Casas 1535-1970" in Friede and Keen, above n 13, 3; and, Juan Comas "Historical Reality and the Detractors of Las Casas" in Friede and Keen, above n 13, 487. In Latin America, Las Casas' reputation has varied to some extent from country to country; for example, he is admired in Mexico - in fact the city of San Cristóbal de las Casas is named after him - while the views of Argentinian historians, much influenced by trends in Spain in the 1930s and 1940s, have been more ambivalent.

16 Daniel Castro Another Face of Empire: Bartolomé de las Casas, Indigenous Rights and Ecclesiastical Imperialism (Duke University Press, Durham (North Carolina), 2007).

17 See Kenneth J Pennington Jr "Bartolomé de las Casas and the Tradition of Medieval Law" (1970) 2 Church History 39 at 149-161. Pennington sees Las Casas primarily as a jurist. 
were some distance apart on the key legal issue of the day: the legal validity of Spanish titles to the New World by papal grant. Vítoria, as will be seen, was a critic of the grants and denied that the pope had authority to make them; Las Casas, while agreeing with Vítoria in rejecting some of the more extreme formulations of the claims to papal sovereignty implicit in the papal bulls of donation, nevertheless believed in the validity of the grants, but believed also that they meant what they said. ${ }^{18}$

\section{THE "BLACK LEGEND" (LA LEYENDA NEGRA), LAS CASAS AND VÍTORIA}

The key historiographical debate which swirls around Vítoria, Las Casas and the Spanish school is that of the leyenda negra, the black legend, a tendency to see the Spanish colonial empire as the ultimate in cruelty, destructiveness and oppression. ${ }^{19}$ Las Casas is one of its principal creators, and some of his works are a catalogue of horrors which few can bear reading for long, a numbing sequence of oppressions and brutalities inflicted on a people regarded by Las Casas as the most inoffensive in the world. The role played by Las Casas as founding father of the black legend has long been resented by many Spanish and Latin American conservative intellectuals, some of whom have questioned his mental stability. The long history of the leyenda negra cannot be traversed here at length, but one particularly illuminating debate of more recent years can be addressed, that between two prominent United States historians of colonial Spanish history: Lewis Hanke and Benjamin Keen.

Lewis Hanke (1905-1993) is the most important modern interpreter of Las Casas in the Englishspeaking world and the author of a number of books about what he describes as the "Spanish struggle for justice" in the 16th century. ${ }^{20}$ Hanke was a warm admirer of Las Casas and saw him as representing Spain at her best. The leyenda negra fails to account for Las Casas himself, a heroic activist and champion of the rights of the Indians. Hanke's work is best seen as an attempt to show

18 See D A Brading The First America (Cambridge University Press, Cambridge, 1991) at 95-96. That is, that the grants were strictly conditional on the duty of the Crowns of Spain and Portugal to spread the Christian faith - by peaceful means, in Las Casas' view.

19 For a contemporary collection of essays dealing with all aspects of the black legend, see Margaret R Greer, Walter D Mignolo and Maureen Quilligan Rereading the Black Legend: The Discourses of Religious and Racial Difference in the Renaissance Empires (University of Chicago Press, Chicago, 2007). On the black legend and the construction of Anglo-American ethnicity, see María de Guzmán Spain's Long Shadow: The Black Legend, Off-Whiteness, and Anglo-American Empire (University of Minnesota Press, Minneapolis, 2005).

20 Lewis Hanke The Spanish Struggle for Justice in the Conquest of America (Southern Methodist University Press, Dallas, 2002) [Spanish Struggle]; Lewis Hanke Aristotle and the American Indians: A Study in Race Prejudice in the Modern World (Indiana University Press, Bloomington, 1959) [Aristotle and the American Indians]; Hanke, above n 14. See also Lewis Hanke "The Dawn of Conscience in America: Spanish Experiments and Experiences with Indians in the New World" (1963) 107 Proceedings of the American Philosophical Society 83 ["The Dawn of Conscience in America"]. 
that the Spanish record in the New World was much more than a story of conquest and exploitation; it was also the occasion for a major debate on justice and human rights which still reverberates at the present day. If Spain produced conquistadores such as Alvarado and the Pizarro brothers, it also could produce Las Casas: ${ }^{21}$

Other nations sent out bold explorers and established empires. But no other European people, before or since the conquest of America, plunged into such a struggle for justice as developed among Spaniards shortly after the discovery of America and persisted throughout the sixteenth century. This study attempts to examine this unique quality of Spanish effort and to show it influenced Spanish action in

America.

The Spanish effort, in Hanke's view, was thus unique, and not duplicated by any other European colonial power. Hanke makes the same claim in his other books. For example, he argues in his Aristotle and the American Indians that "no other nation made so continuous or so passionate an attempt to discover what was the just treatment for the native peoples under its jurisdiction, as the Spaniards", not even, Hanke adds, "the Portuguese".22 (Actually there was a very substantial debate about the "just treatment for the native peoples" in 19th century Britain, arguably far more extensive and important than anything that took place in 16th century Spain; it is more true to state that no other nation at the time, or for quite some time to come, had such a debate. ${ }^{23}$ ) Hanke's claim is one which, if true, makes a serious inroad into the leyenda negra. Far from exemplifying the worst excesses of colonialism, it was Spain, Hanke believes, which subjected itself to the most searching scrutiny of the legitimacy and morality of its actions, a process of inquiry which the Portuguese, Dutch, French and English failed to match. To this, however, it can be replied that in the case of colonisation by the Protestant English and Dutch no role could be played by the great Catholic

21 Hanke Spanish Struggle, above n 20, at 1 (emphasis added).

22 Hanke Aristotle and the American Indians, above n 20, at 107 (emphasis added). Portugal is not in fact commonly suspected of having made much of an effort to protect indigenous peoples or indeed of having had a debate about the matter.

23 See for example HG Koenigsberger and George L Mosse Europe in the Sixteenth Century (Longmans, London, 1968) at 211:

It is one of the ironies of history that Las Casas' deliberate indictment of the Spanish conquistadores and colonists should have become one of the sources of the 'black legend' against Spain, used as antiSpanish propaganda by nations whose colonial record was to be no whit better than that of the Spaniards and who hardly even began to discuss the moral problems of empire until the eighteenth century.

But there are contemporary parallels that could be analysed. A systematic comparison of Spanish debate about the New World and English discussion about plantation and settlement in Ireland and in the New World would be very illuminating. On Ireland, see especially Nicholas Canny Making Ireland British 1580 1650 (Oxford University Press, Oxford, 2001); John Kerrigan Archipelagic English: Literature, History and Politics (Oxford University Press, Oxford, 2008). 
international missionary orders and societies such as the Dominicans and the Jesuits: ${ }^{24}$ the debate and soul-searching in Spain could be said to be as much a credit to the Dominican order as such as it was to the "Spanish"; and that when French colonisation in Canada began in the 17th century the Jesuits were certainly influential as advocates for the Native peoples of eastern Canada. In any event, Hanke is careful to note that "the ideals announced by the Spanish crown" were not necessarily actually implemented in the colonies; "[n]or should anyone claim that the Spaniards fully accomplished their purpose: to incorporate the mass of New World Indians into a Christian and European world". 25 In Hanke's view, Spain was distinctive not so much for what it actually achieved than for at least having a serious debate about what it was doing, a debate which genuinely did impact on the formation of Crown policy.

Hanke's arguments about Spanish distinctiveness were contested by the prominent historian Benjamin Keen in 1969, author of a well-known book on the post-conquest image of the Aztecs amongst European and Latin American writers, ${ }^{26}$ who suggested that Hanke was resurrecting a "white legend" of a Spanish search for justice to replace an admittedly exaggerated black legend. ${ }^{27}$ Keen argued that Las Casas' works enjoyed only a limited circulation in Spain itself, and that after 1600 "the memory of Las Casas fell under a heavy cloud" in his country of origin. In Keen's view, Las Casas' impact on actual Crown policy and practice was slight. Keen noted a "central paradox" in Hanke's approach - the use of Las Casas, Spain's most severe contemporary critic, to ameliorate the evil reputation of the very policies and actions that Las Casas excoriated. To put Keen's point another way, it is rather like arguing that Stalinist Russia could not have been so bad as after all it produced Alexander Solzhenitsyn and Boris Pasternak. According to Keen: ${ }^{28}$

Hanke's works contain a certain paradox. The central figure in Hanke's studies on intellectual history, the figure whose greatness as a humanist, historian, and anthropologist he has so ably and amply documented, is Las Casas, the supposed source of the Black Legend.

24 A point made by JH Elliott Empires of the Atlantic World: Britan and Spain in America (Yale University Press, New Haven 2006) at 67.

25 Hanke "The Dawn of Conscience in America", above n 20, at 91. Hanke was writing at a time when it could still be confidently assumed that the latter goal was ipso facto desirable.

26 Benjamin Keen The Aztec Image (Rutgers University Press, Chapel Hill (North Carolina), 1971).

27 Benjamin Keen "The Black Legend Revisited: Assumptions and Realities" (1969) 49 Hispanic American Historical Review 703. Keen does not claim that Spain was uniquely bad, just that all the colonising powers were in their varying ways as bad as each other. I would argue in fact that the colonising power in the Americas which had the most imaginative and considered relationships with the indigenous nations was in fact France, a point which it is not necessary to pursue here.

28 Ibid, at 706. 
While Keen does not see Spain's behaviour as either better or worse than that of other colonising powers, the reality of the Spanish colonial empire was one of coercion and oppression, and in this sense, to Keen, the black legend is in fact nothing less than the truth: ${ }^{29}$

... the so-called Black Legend is substantially accurate, if stripped of its rhetoric and emotional coloration, and with due regard for its failure to notice less dramatic forms of Spanish exploitation of the Indians (land usurpation, peonage and the like). Consequently it is no legend at all, and the term lacks scientific descriptive value. Acceptance that the traditional critique of Spanish colonial practices was valid in no way implies superior practice by other imperialisms. Nor does it preclude an equal stress on Spanish colonial achievements, ranging from the devoted labors of many clergy in the fields of scholarship, education and protection of the natives to the cultural flowering that occurred in some parts of the region during the eighteenth century.

Keen's rather complex point is that certainly the black legend is true in emphasising the exploitative and coercive nature of Spain's authority; on the other hand, the empire was also marked by many impressive achievements, especially in the fields of high culture and the arts. Finally, Keen implies, other colonial powers - Britain, France, Portugal (and, I would add, the United States and ex-colonial societies such as Argentina, Chile, Guatemala and Australia) - have no right to point the finger at Spain.

It is obviously not possible in an introductory survey article of this kind to analyse the entire historiography relating to the Spanish colonial empire, but it is fair to say that Keen's view that the efforts of Spanish scholars and writers such as Las Casas and Vítoria had only a limited impact on colonial realities is the general consensus of modern historical scholarship. ${ }^{30}$ That, of course, does not mean that these two key figures are for that reason alone deprived of historical significance. The Spanish colonial empire in the New World was a vast edifice that lasted for three centuries with marked regional divergences and large gaps between law and policy on the one hand, and colonial realities, on the other, and thus it is important not to over-generalise. It was a patrimonial society of castes, hierarchies and competing jurisdictions: a Baroque world in every way. No one could call the

29 Ibid, at 719. See also Lewis Hanke "A Modest Proposal for a Moratorium on Grand Generalizations: Some Thoughts on the Black Legend" (1971) 51 Hispanic American Historical Review 112; Benjamin Keen "The White Legend Revisited: A Reply to Professor Hanke's 'Modest Proposal'" (1971) 51 Hispanic American Historical Review 336.

30 For important recent accounts dealing with the history of the empire, see David Abulafia The Discovery of Mankind: Atlantic Encounters in the Age of Columbus (Yale University Press, New Haven, 2008); Brading, above n 18; Pierre Chaunu Conquête et exploitation des nouveaux mondes (Presses universitaires de France, Paris, 1969); Elliott, above n 24; Kamen, above n 7; Lyle N McAlister Spain and Portugal in the New World (University of Minnesota Press, Minneapolis, 1984); Hugh Thomas Rivers of Gold: The Rise of the Spanish Empire (Weidenfeld \& Nicolson, London, 2003). 
Spanish colonial empire an open or free society. ${ }^{31}$ It is true that the enslavement of indigenous peoples was forbidden by imperial law, a rule that was generally adhered to, but the empire was also characterised by a wide range of oppressive and exploitative devices designed to extract surpluses from subject populations. The reality of exploitation and oppression has been documented in scores of detailed monographs. ${ }^{32}$ Any belief that the Spanish were more enlightened and sympathetic to indigenous peoples than were the English or the French has no foundation. In fact, if any European power could claim any kind of exceptionalism in this respect, that power could only be France. ${ }^{33}$ Certainly claims of Spanish distinctiveness must be regarded as unfounded.

31 See Octavio Paz Sor Juana de la Cruz: Las Trampas de la Fe (Fondo de Cultura Económica, México, 1982) at 66. Octavio Paz in fact likens colonial New Spain (Mexico) to a kind of fortress, built around the institutions of the Viceroy's Court, the town council and the cathedral, flanked by the monastic convent, the university and the military fort, "but the convent and the university are likewise fortresses: they defended New Spain not from pirates or nomadic Indians but rather from the passing of time" ("[p]ero el convento y la universidad también era fortalezas: no defendían a la Nueva España de los piratas y de los nómadas sino del tiempo"). New Spain "was not built to change but rather to endure" ("Nueva España no estaba hecha para cambiar sino para durar").

32 Only some representative books out of a rich and colossal literature can be cited. For some key regional and local studies, see Luis F Calero Chiefdoms under Siege: Spain's Rule and Native Adaptation in the Southern Colombian Andes, 1535-1700 (University of New Mexico Press, Albuquerque, 1997); Laura Caso Barrera Caminos en la selva: Migración, comercio y resistencia: Mayas yucatecos y itzaes, siglos XVII-XIX (Colegio de México y Fondo de Cultura Económica, México, 2002); Nancy M Farriss Maya Society under Colonial Rule: The Collective Enterprise of Survival (Princeton University Press, Princeton, 1984) (Yucatan); Ramon A Gutiérrez When Jesus Came, the Corn Mothers Went Away: Marriage, Sexuality, and Power in New Mexico, 1500-1846 (Stanford University Press, Stanford, 1991) (New Mexico); W George Lovell Conquest and Survival in Colonial Guatemala (McGill-Queen's University Press, Montreal, 1992) (Guatemalan highlands); Severo Martínez Peláez, Susan M Neve (trans) and W George Lovell (trans) La Patria del Criollo (Duke University Press, Durham, 2009); Karen Spalding Huarochirí: An Andean Society under Inca and Spanish Rule (Stanford University Press, Stanford, 1984) (Peruvian Andes); Steve J Stern Peru's Indian Peoples and the Challenge of Spanish Conquest: Huamanga to 1640, (2nd ed, University of Wisconsin Press, Madison, 1993) (Peruvian Andes); Jan de Voz La paz de Dios y del Rey: La conquista de la selva Lacandona (Fondo de Cultura Económica, México, 1980) (Chiapas). This list could be prolonged substantially in English and more or less indefinitely in Spanish. Much of the more recent work is concerned to show that indigenous peoples of the Americas were not simply merely passive victims, but continued to be active makers of their own history. It is important to emphasise that by no means do all of these writers see the process of Spanish colonialism as simply or only a narrative of oppression and exploitation. Some other writers go out of their way to stress the more positive aspects of the colonial encounter. For a recent account which stresses convivencia (roughly, "getting along") on the frontier, see John Kessell Pueblos, Spaniards and the Kingdom of New Mexico (University of Oklahoma Press, Norman, 2008).

33 French policy in Canada compares very favourably with the behaviour of the English and Spanish in North America, and France definitely had the most imaginative and equal diplomatic relations with the Indian nations (admittedly largely out of necessity). On Canada, see especially David Hackett Fischer Champlain's Dream: The Founding of North America (Simon and Schuster, New York, 2008); James Pritchard In Search of Empire: The French in the Americas, 1670-1730 (Cambridge University Press, Cambridge, 2004). 


\section{THE SPANISH ORIGINS OF INTERNATIONAL LAW}

Related to the claim of Spanish exceptionalism is the argument that Vitoria and others of the Salamanca school - Las Casas does not seem to figure prominently in the analysis - created "international law" as that term is understood today. The most ardent 20th century champion of Vítoria in the Anglophone world was James Brown Scott, Professor of International Law at Georgetown University, who was in no doubt that Vítoria was the founder of modern international law. The very title of his book, The Spanish Origin of International Law: Francisco de Vitoria and his Law of Nations, ${ }^{34}$ published in 1934 with the support of the Carnegie Endowment for International Peace, says it all. Scott was sympathetic to natural law jurisprudence and had close links with Spain and some of the Latin American republics. An ardent admirer of Vítoria, he was closely involved in the establishment of the Associación Francisco de Vítoria in Spain in 1928. The new body was founded after a conference held at Salamanca in 1926 to celebrate the 400th anniversary of Vítoria's appointment to the prima chair of theology at Salamanca, "from which he gave", Scott writes, "for the first time, an acceptable definition of international law and of its sources, and professed its principles applied to the concrete facts of international life". ${ }^{35}$ However, the world of scholarship has changed a great deal since gentlemanly scholars from Europe and the United States could meet at Salamanca to establish an international body dedicated to Vítoria and international law barely a decade before the outbreak of the Spanish Civil War. Scott's work has itself now become the focus of a barrage of criticism. He has, for instance, been accused of presenting a naively celebratory and "de-historicized" picture of Vítoria in a recent article by Fernando Gomez. ${ }^{36}$

Just as Scott sourced international law in 16th century Spain, similarly Felix Cohen sourced federal Indian law in Vítoria and his successors. ${ }^{37}$ Cohen was no naturalist, but a leading member of the American Realist school, and a prominent New Deal liberal who played a leading role in drafting key legislation relating to American Indian tribal organisation and the resolution of Indian historic claims against the federal government. ${ }^{38}$ Nevertheless, his approach is very similar to that of James Brown Scott: Cohen admits that it would be "childish" to ignore "the inhumane aspects of the Spanish conquest of the New World", but that the "the legal ideals which Spanish teachers

French-Indian diplomatic relations are treated fully in Richard White The Middle Ground: Indians, Empires and Republics in the Great Lakes Region 1650-1815 (Cambridge University Press, Cambridge, 1991).

34 Scott The Spanish Origin, above n 9.

35 James Brown Scott "Asociación Francisco de Vítoria" (1928) 22 AJIL 136 at 137.

36 Fernando Gomez "Francisco de Vitoria in 1934, Before and After" (2002) 177 MLN 365.

37 Felix Cohen "The Spanish Origin of Indian Rights in the Law of the United States" (1942) 31 Geo LJ 1.

38 On Cohen, see Dalia Tsuk Mitchell Architect of Justice: Felix S Cohen and the Founding of American Legal Pluralism (Cornell University Press, Ithaca, 2007). 
proclaimed, and which Crown and Holy See ratified, provided a humane and rational basis for an American law of Indian affairs". ${ }^{39}$ Cohen's famous article on the "Spanish Origin of Indian Rights in the Law of the United States" (1942) should best be seen as an extension of James Brown Scott's thesis regarding the origins of international law to federal Indian law, Cohen's particular area of interest and expertise. ${ }^{40}$ But the importance of international law as a conduit is retained, as Cohen argued that the Spanish school created a body of international law doctrine relating to the rights of indigenous peoples which in turn fed its way into United States law through Chief Justice John Marshall's decisions relating to the status of Indian nations and the extent to which they were affected by the doctrine of sovereign immunity. ${ }^{41}$ International law was one of a number of means by which Spanish law impacted directly on federal Indian law, and, following Scott, Cohen likewise sees international law as arising in 16th century Spain.

Although naturalist writers do continue to bracket Vítoria and Las Casas together and extol them, along with Suárez and other Spanish scholars, as founding fathers of international law, other scholars of international law writing today now tend to reject this. In an influential article published in the Harvard Journal of International Law in 1986, David Kennedy grouped Vítoria with Suárez, Gentili and Grotius as representatives of the phase of "primitive legal scholarship" of international law. ${ }^{42}$ Kennedy's reading of Vítoria and Suárez has been followed and developed by Martii Koskenniemi, ${ }^{43}$ a leading contemporary international law theorist and historian of international law jurisprudence. Neither Kennedy nor Koskenniemi feel able to see the development of contemporary international law as evolving in any kind of linear way from Vítoria and his followers. Kennedy is particularly wary of the claim that the soi-disant "primitives" ought to be seen as the founders of modern international law: 44

39 Cohen, above n 37 , at 9.

40 See also Richard P Boast "Felix Cohen and the Spanish Moment in Federal Indian Law: A Study in Law, Politics and Historiography" (2008) 29 VUWLR 419.

41 Cohen, above n 37, at 17:

... we must recognize that our Indian law originated, and can still be most clearly grasped, as a branch of international law, and that in the field of international law the basic principles were all hammered out by the Spanish theological jurists of the sixteenth and seventeenth centuries, most notably by the author of the lectures De Indis, Francisco de Vítoria.

The Supreme Court decisions referred to are: Johnson v M'Intosh 21 US 543 (1823); Cherokee Nation v Georgia 30 US 1 (1831); and, Worcester v Georgia 21 US 515 (1832)

42 David Kennedy "Primitive Legal Scholarship" (1986) 27 Harv Int'l Law J 1.

43 Martti Koskenniemi From Apology to Utopia: The Structure of International Law Argument (Cambridge University Press, Cambridge, 2005) at 95-106. Koskenniemi basically follows Kennedy's analysis of Vítoria and the other "primitives".

44 Kennedy, above n 42 , at 5. 
The tone, method and doctrinal argument of these texts suggest that primitive legal scholars addressed international problems similar to those treated by later scholars, but in a fashion so dissimilar from later work that historians who focus on the primitives' role as "founders" of modern international law, distort the primitive texts' opposition to modernity.

To Kennedy and Koskenniemi, what is most striking about "primitive" international legal scholarship is the complete absence of differentiation between normative rules: scripture, passages from Aristotle, papal bulls and decretals and the remarks of the Church fathers are all cited, as it were, in the same breath, as illustrative of a universal moral-legal order which is binding on everyone and everywhere. Kennedy sees in Vítoria a "conflation" of morality and law. It is not that Vítoria develops a moral or ethical critique of "law"; rather, any distinction between law and morality is simply meaningless to him. Vítoria "does not suggest any rule which is morally but not legally binding". ${ }^{45}$ Thus, Vítoria's treatise De Indis begins quite unselfconsciously with a passage from St Matthew's gospel, chosen not as illustrative or to make a theological point, but rather as simply normative. ${ }^{46}$ As Kennedy puts it: ${ }^{47}$

In fact, Vítoria's texts contain no explicit or implicit distinction of the binding power of the moral or divine and legal orders. Distinctions made in the shorter conceptual works turn out to be fundamentally different from the separation of moral and legal obligation with which later theorists are familiar. For example, although they distinguish ecclesiastic and civil power, spiritual and temporal authority, and mortal and venial sin, Vitoria does not imagine a human law whose binding force arises other than from divinely ordained morality or which binds in action but not in conscience. Vitoria does not "argue" that sovereigns can not disagree about such things, he assumes it.

Kennedy sees the "primitives" as very self-assured; ${ }^{48}$ in their writing, "legal authority and doctrinal result" are connected in a "direct and unproblematic fashion". ${ }^{49}$ Authorities are cited in a kind of scatter-gun way, but are not ranked or analysed: ${ }^{50}$

Primitive scholars invoke a variety of textual authorities, ranging from the Gospel and scholastic authors to various ancient and medieval jurists. These constitute a catalog of available citations, each authoritative whenever invoked. The primitive does not engage in argument among citable propositions or authorities. Each doctrinal position is simply linked to one or another without internal criticism. The
45 Ibid, at 17
46 Ibid, at 15.
47 Ibid, at 16 (emphasis added).
48 See ibid, at 5.
49 Ibid.
50 Ibid, at 6 . 
resulting scheme of authority seems diverse, incoherent and analytically unsatisfying to the modern reader.

Specifically in Vítoria's case: ${ }^{51}$

$[\mathrm{H}]$ is tone is consistently authoritative and unproblematic. Nowhere does he address his methodology or the relative value of various authorities on which he relies. In doctrinal discussions, Vitoria cites one passage after another from Scripture, from St Thomas Aquinas, or from one or another ancient philosophical text, without mentioning any technique or canon for selecting such citations. He does not compare citations or use one citation to criticize another, although he occasionally strings together a list of citations, each of which supports some proposition in its own way. The references are simply quoted or paraphrased and attached to a doctrinal problem or solution.

The treatment of the American Indians is discussed and resolved entirely within a Catholic and Aristotelian intellectual framework that Vítoria treats, without reflection, as universally binding.

However, Vítoria was not a lawyer of any sort, and never saw himself as one. In the opening sections of De Indis, Vítoria explains carefully the task which lies before him. He begins De Indis by asking, first, why it might be that an inquiry as to the justice of Spanish titles be embarked on at all, given that: ${ }^{52}$

... neither the princes of the Spains nor the ministers of their royal Councils are obliged to justify anew rights and titles which have already been deliberated and judged, especially since the territories in question are occupied in good faith and are now held in pacific possession by the Spanish Crown.

Vítoria goes on, however, to note that while there is no point in having deliberations "in cases of indisputable lawfulness and goodness or indisputable unlawfulness and evil" - for example, "no one should debate whether a life of courage, temperance and justice is better than a life of injustice, infamy, adultery and so on" it is otherwise with matters of "reasonable doubt". ${ }^{53}$ If it is a matter of real doubt, moral or ethical doubt, then, says Vitoria, it is sinful and wrong to proceed without consulting "wise men". One should not simply rely on one's own judgment and assessment of matters but should consult the authorities. We must act according to our conscience, certainly, but to an informed and guided conscience, perhaps a very Catholic viewpoint. And with regard to the justice of Spain's claims in the Americas, at the very least it has to be admitted that there is ground for doubt as to the justice of Spanish behaviour: "when we hear subsequently of bloody massacres and of innocent individuals pillaged of their possessions and dominions, there are grounds for

51 Ibid, at 15 .

52 Vítoria, Pagden and Lawrance, above n 8, at 234.

53 Ibid. 
doubting the justice of what has been done". ${ }^{54}$ Here Vitoria is careful to emphasise that the issue of Spain's title to the New World is a question of ethics and morality, not law: ${ }^{55}$

... I say that it is not the province of lawyers, or not of lawyers alone, to pass sentence in this question.

Since these barbarians we speak of are not subjects [of the Spanish Crown] by human law (iure

humano), as I shall show in a moment, their affairs cannot be judged by human statutes (leges

humanae), but only by divine ones, in which jurists are not sufficiently versed to form an opinion on

their own. And as far as I am aware, no theologian of note or worthy of respect in a matter of such

importance has ever been called upon to study this question and provide a solution. Yet since this is a

case of conscience, it is the business of the priests, that is to say of the Church, to pass sentence upon it.

These remarks of Vítoria's may go some way to answering Kennedy's argument that it is not possible to see Vítoria as a "father" of international law for the reason that what Vítoria treats as normative fails to distinguish between different kinds of norms: moral, scriptural and more strictly legal. But Vítoria is not embarking on a legal discussion - indeed he states very clearly that he is not. He recognises that lawyers, "jurists", have their own proper sphere of expertise, but the questions he is concerned with are not in fact questions of law, which would of course include canon law. The issues at stake are questions of conscience, or morality, and it is the Church and her priests who are, as it were, the professional experts on such matters, and who have their own proper texts, sources of authority and so forth. The blending together of scripture, Aristotle and the Church fathers that Kennedy finds so striking is simply characteristic of the scholastic theology of the day. The significant question to ask about Vítoria is, surely, not whether he works within an Aristotelian and Thomist frame of reference, which he clearly does, but what is distinctive about him judged from within the perspective of that framework.

\section{REVISIONIST ANALYSES: ROBERT WILLIAMS AND DANIEL CASTRO}

So far we have encountered writers who see Vítoria and Las Casas as playing a vital and beneficial role in ameliorating the worst excesses of Spanish colonial expansion and laying the foundations of international and human rights law. However, no review of the historiography can be complete without taking account of those who see the influence of Vítoria - and others - as both hugely important and as malign and destructive from an indigenous rights perspective. Revisionist approaches as exemplified by Robert Williams and Daniel Castro start by setting up colonialism or imperialism as an absolute moral evil, one moreover that Western Europe has allegedly been particularly addicted to, and then try to show that particular individuals usually thought to be critics of colonial expansion were in fact as implicated in it as everyone else and may have even served to legitimise it.

54 Ibid, at 238 .

55 Ibid. 
Robert Williams, author of a sequence of lengthy articles in various United States law reviews later consolidated into his American Indian in Western Legal Thought (1991), is a key figure in English-language legal scholarship on the legacy of the Spanish school. ${ }^{56}$ Like the naturalist Scott and the realist Cohen, the critical legal studies scholar Williams sees Vítoria and the Spanish school as important; unlike them he sees the Spanish legacy in a resoundingly negative light - in fact as the foundation stone of a body of doctrine that is "racist" at heart. As he puts it in the introduction to his book:

... law and legal discourse were the perfect instruments of empire for Spain, England and the United

States in their colonizing histories, performing legitimating, energizing and constraining roles in the

West's assumption of power over the Indian's America.

To understand Williams' particular critique it is necessary to return to Vítoria himself and the particular arguments he develops in De Indis.

The central puzzle with Vítoria lies in his attack on the papal bulls of donation of 1493 by which Spain claimed jurisdiction over the Americas, as modified by the Hispano-Portuguese Treaty of Tordesillas of 1494. The papal grants, which allocated jurisdiction over the non-Christian world to Portugal and Spain, were based on the theory of the universal jurisdiction of the papacy. Christ, on his coming into the world - so the argument ran - acquired supreme lordship over it both in a spiritual and a temporal sense, a power that Christ bestowed on the first of the popes (St Peter) and which has been passed down historically to the papacy of Vítoria's day. As Vítoria notes, "it is the opinion of some jurists that the pope has plenary jurisdiction in temporals throughout the whole world". ${ }^{57} \mathrm{He}$ points out as well that this theory certainly informed what actually happened in $1493-$ 1494. Nevertheless, the pope is "not the civil or temporal master over the whole world, in the proper meaning of 'dominion' and 'civil power"'. ${ }^{58}$ In fact, Christ himself did not have temporal (political) power of the world: as He did not, how then could such power have ever been bestowed on the papacy? Although Christ commanded St Peter to "[f]eed my sheep", 59 that, says Vítoria, is a

56 Robert A Williams The American Indian in Western Legal Thought: The Discourses of Conquest (Oxford University Press, New York, 1990) [The American Indian in Western Legal Thought]; Robert A Williams "The Medieval and Renaissance Origins of the Status of the American Indian in Western Legal Thought" (1983-1984) 57 S Cal L Rev 1 ["Medieval and Renaissance Origins"].

57 Vítoria, Pagden and Lawrance, above n 8, at 258. On the debate within medieval Catholicism as to the extent of papal jurisdiction, see Robert Bireley The Refashioning of Catholicism, 1450-1700: A Reassessment of the Counter Reformation (Catholic University Press, Washington (DC), 1999) at 147-174; Walter Ullmann Law and Politics in the Later Middle Ages (Cornell University Press, Ithaca, 1975); James Muldoon Popes, Lawyers and Infidels: The Church and the Non-Christian World (Liverpool University Press, Liverpool, 1980); James Muldoon Canon Law, the Expansion of Europe, and World Order (Ashgate Publishing, Aldershot (United Kingdom), 1998).

58 Vítoria, Pagden and Lawrance, above n 8, at 260.

59 John 21:17. 
reference to power in a spiritual and not a temporal sense. ${ }^{60}$ In fact, the pope does not even have spiritual power over the whole world. The pope's temporal power is subordinate to his spiritual power, but as the pope has no spiritual power over the Indians of the Americas (they are not Christians) a fortiori he can have "no temporal power either". ${ }^{61}$ Vítoria's rejection of the foundation of famous claims is total. That much is clear. The question is, why does Vítoria, a good Catholic and loyal subject of the Spanish Crown, do this? That is far less clear, and indeed has provoked massive disagreement. To Williams, the key to understanding Vítoria is that section of De Indis which follows on from his rejection of Spanish titles based on papal grant.

In Part III, Vítoria, having rejected the validity of the papal grants of 1493, next embarks on a further enquiry as to whether Spain may nevertheless still have a "just title" to the Indies. He concludes that it does. Vítoria's starting point is that the jus gentium, the law of nations, is binding on all; no one can opt out of it. But what are the sources of this law of nations? Williams points out that the sources of the jus gentium are derived from "a variety of privileged sources, all Western and thoroughly Christo-Eurocentric in their normative orientation". ${ }^{62}$ As he puts it: ${ }^{63}$

Roman law, Holy Scripture, St Augustine, classical writers, St Thomas [Aquinas], and other authorities were all marshalled by Victoria [sic] in typical scholastic fashion to support his central thesis that all "civilized" societies recognized as set body of natural-law rules binding their conduct in the international sphere.

But then, to repeat the same point made in response to Professor Kennedy's similar observations, this is not really surprising. Without meaning to be flippant (the point is meant seriously), what other sources might one expect a 16th century neo-Thomist theologian to draw upon? One would not expect him to cite the Koran or the works of the great Jewish philosopher Maimonides, still less Christian heretics such as Wycliff, Hus or Martin Luther. Vítoria taught in a country where, after all, the government had overthrown the last Moslem State in the peninsula (in 1492) and had subsequently prohibited Islam, which expelled the entire Jewish population of Castile and Aragon (also in 1492) and had established the Spanish Inquisition.

Vítoria now goes on to construct a completely new set of norms which arguably gives Spain a "just title" to its possessions in the New World, deriving from natural law duties and rights: the

60 Vítoria, Pagden and Lawrance, above n 8, at 260: "It is clear enough that he meant that his power was spiritual, not temporal".

61 Ibid, at 262-263:

$\ldots$ if the pope has no temporal power except in relation to spiritual matters, and if 1 Cor 5:12 shows that he has no spiritual power over the barbarians, it follows that he can have no temporal power over them either.

62 Williams The American Indian in Western Legal Thought, above n 56, at 101.

63 Ibid. 
rights of Spaniards to travel to the Indies, the right to engage on commerce and trade and the obligation imposed on the Indians to permit the peaceful preaching of the Christian faith. I do not have space to analyse Vítoria's argument fully here, or Williams' commentary on it. In a nutshell, Williams sees Vítoria's analysis as no less fantastic and manic than the theory of the right of the papacy to grant the world to the kings of Spain and Portugal that has just been repudiated. Vítoria's analysis, Williams states, "led him to deny the legitimacy of papal hierarchical domination, while on the other hand [it] permitted him to legitimate a functionally equivalent Spanish hierarchical subordination of the Indian". ${ }^{64}$ In this view, Vítoria is essentially engaged in legitimising Spanish authority in the New World, but legitimising it on new, albeit equally universal and Eurocentric, foundations. To Williams "Victoria was no radical proto-egalitarian seeking ultimately to free the Indian from Spanish Christian hegemony"; rather, "his discursive practice was thoroughly medieval in its totalizing trajectory, desire for plenitude of a rationalized world order, and critical focus on the Indians' normative difference"; the "Dominican's famous defence of Indian rights under natural law did not emancipate the Indians from the guardianship of Christian Europe". ${ }^{65}$ Williams' Vítoria is as different from Scott's and Cohen's Vítoria as could be imagined; indeed, it hardly seems possible that they are writing about the same person.

Williams' analysis overlooks the fact that Spain never did discard claims to sovereignty in the Americas based on papal grant; this actually remained the principal justification for Spanish territorial claims. The theory of papal grant had the virtues of simplicity and clarity as far as the Spanish Crown was concerned. The doctrine of terra nullius never entered the framework of Spanish colonial law as there was no need for it to do so. As JH Elliott emphasises. ${ }^{66}$

In claiming sovereignty ... the Spaniards, unlike the English, had little or no need of the doctrine of res

nullius, since their title was based on the original papal cession to the Spanish crown.

The papacy remained a natural reference for Spaniards and Spanish Americans in matters of international law for centuries. In fact, even as late as 1906, the republics of Peru and Colombia can be found submitting a border dispute between them to mediation by Pope Pius X. ${ }^{67}$ Williams thus certainly exaggerates the significance of Vítoria's repudiation of the papal grants: if his true significance lies in a modernisation of Spain's claims to title in the New World, it seems strange that the Crown never took much note of it. Nevertheless, Williams' critique is undoubtedly the most important revisionist analysis of Vitoria and the Salamanca school to date, and his analysis of Vítoria seems convincing in many respects. To put the position in a moderate way, those who see

64 Williams "Medieval and Renaissance Origins", above n 56, at 86.

65 Williams The American Indian in Western Legal Thought, above n 56, at 97.

66 Elliott, above n 24, at 30.

67 See John Hemming Tree of Rivers: The Story of the Amazon (Thames and Hudson, London, 2008) at 204205. 
Vítoria and his successors as founding fathers of international law and the law relating to indigenous peoples must reckon with Williams' powerful critique which, on the contrary, sees him as a founder of a body of thought which denies indigenous forms of political organisation any kind of recognition. That Vítoria's thought is "totalizing" is something that David Kennedy would presumably not dispute, even if he might not quite put it that way.

Until recently, Las Casas, while sometimes perceived in a hostile light by conservative modern Spanish and Latin American scholars such as Ramón Menéndez Pidal, has remained immune from criticism from critical legal studies writers, Las Casas' credentials as an activist and champion of Indian rights being, one might think, hard to deny. Indeed some prominent Latin American liberation theologians have sought to link their own brand of Catholic theology with Lascasian thought, one prominent example being the Peruvian theologian Gustavo Gutiérrez. ${ }^{68}$ Williams concentrates his energies on Vítoria and has little to say about Las Casas. To put it crudely, until now Las Casas has been attacked from the right, rather than the left. However, a new book by Daniel Castro on Las Casas may mark an important shift in direction. ${ }^{69}$ Just as Williams has attempted a demolition job on Vítoria, Castro has now tried to do the same to Las Casas. Like Williams, Castro writes from a pro-indigenist critical legal studies stance and his book is something of a new departure. But how successful is it?

Castro begins by arguing that making a real assessment of Las Casas is now difficult because of the leyenda negra historiographical debate. Conservative Spanish writers, seeking to replace the black legend with a contrasting "white" or "golden" legend of their own, have felt it necessary to demonize and vilify Las Casas as a liar or as mentally disturbed, while those believing in the black legend tend to see him as a saintly activist of irreproachable virtue. As Castro puts it, critics see him as a "pious fanatic", while to his admirers he is "variously seen as an apostolic prototype of love, a noble protector of the Indians, or, as some have called him, the 'father of America"'. ${ }^{70}$ None of this rhetoric, Castro suggests, is very helpful in trying to really grasp what Las Casas was about or his true significance, and one can only agree. (Castro is not, however, the first person to notice the different interpretations of Las Casas and seek to devise an escape route.) How, then, should he be seen? Castro's analysis is grouped around three main ideas. First, Las Casas in many ways was a failure. Many of the projects he attempted failed, either because they were poorly thought-out and impractical, ${ }^{71}$ or because Las Casas lost interest in them and moved on to something else. Secondly,

68 Gustavo Gutiérrez En busca de los pobres de Jesucristo: El pensamiento de Bartolomé de las Casas (Instituto Bartolomé de las Casas, Lima, 1992).

69 Castro, above n 16.

70 Ibid, at 4 .

71 Ibid, at 5: 
Las Casas never really had any real imaginative sympathy with the indigenous peoples of the Americas. He never really engaged with them, never learned any of their languages - unlike, for example, Franciscans such as Motolinía, Sahagún or Diego de Landa - and always saw them, says Castro, as lesser beings deserving of pity and guidance rather than as equals and the representatives of a great cultural tradition deserving of respect. Finally, and most importantly, Las Casas was a believer in the Spanish colonial project completely. He wished to humanise and ameliorate it, up to a point at any rate, but he certainly believed in Spain's imperial mission, and was in no doubt that Christianisation of the indigenous peoples of the Americas was an absolute moral imperative and Spain's special destiny. Las Casas was characterised by an "overriding conviction of the innate superiority of his religious beliefs over those of the Native Americans he so wanted to protect". ${ }^{72} \mathrm{He}$ thus differed from other Spanish imperialists only somewhat in degree, and not in substance: ${ }^{73}$

If the difference between Las Casas and his compatriots was one of form and not of essence, then rather than viewing him as the ultimate champion of indigenous causes, we must see the Dominican friar as the incarnation of a more benevolent, paternalistic form of ecclesiastical, political, cultural, and economic imperialism rather than as a unique paradigmatic figure. In this context, he must be re-evaluated as a representative of another face of Spanish ecclesiastical imperialism, albeit a more benevolent form of imperialism than the one offered by the traditional colonists.

Castro's Las Casas has much in common with Robert Williams' Vítoria. Both are accused, at the end of the day, of being the props of the empire rather than its critics.

One can take issue with some aspects of this. It probably should not be held against Las Casas that he spent a lot of time at Court and in Spain, rather than living amongst the Indians of the New World: that was the way to achieve practical outcomes. Las Casas' own historical writings in fact do reveal a sensitive empathy towards the high cultures of indigenous America, about which he was well informed and wrote a great deal. The principal rejoinder to Castro would seem to me to be, however, that he is very largely hammering on an open door. Few of Las Casas' admirers would see him as a cultural relativist. Nor would they dispute that his life was marked by many failures and disappointments. The principal problem with Castro's book seems to be the claim that at the end of the day Las Casas differed from other Spanish imperialists - let us say, the Pizarro brothers, the venal members of the First Audiencia of Mexico, Governor Velázquez of Cuba or Pedro de Alvarado, the conqueror of Guatemala - only in degree. Essentially, Castro thinks, they were all

Las Casas was an activist, and, as such, he was measured by the results he obtained, but this did not always result in long-range beneficial outcomes for the oppressed natives, and often his utopian proposals had the opposite result of what he intended.

This is probably not an uncommon fate with utopian proposals.

72 Ibid, at 9

73 Ibid, at 8 
engaged in the same enterprise. But were they? Yes, but only in the very broadest sense. It is necessary to discriminate. Between Las Casas and Pedro de Alvarado there is a colossal gulf: they were unlike in every respect and had radically different priorities. To bracket such contrasting figures as essentially part of a single and coherent imperial project carries very real risks of a loss rather than a gain in historical understanding. To put it another way, most historians would see the differences between Las Casas and other representative Spanish figures of his day as much more important and more explanatory than the similarities. Such, at least, would be my own stance.

\section{CONTEXTUALIST READINGS}

Under this heading, I wish to bring together a different group of analyses of Vítoria and the Salamanca school that seeks neither to extol nor denigrate them, nor appropriate them as founding fathers of international law or human rights law or indigenous people's law, nor yet to bring them within a juristic project of reconstructing international law on naturalist lines. Rather, the objective is simply to set the Spanish scholars closely in the context of their times, especially in relation to debates over heresy and orthodoxy within early-modern Catholicism, but also as part of a process of analysis and debate in the field of political theory provoked by the rapid expansion of Spanish authority into not only the New World, but into the Netherlands and Italy as well. While much - too much - of what is written and believed about the Spanish school ignores tensions within the Church in the 15th century and the emergence of confessional strife between Protestants and Catholics in the 16th century, contextualist writers such as Anthony Pagden see these developments as the key to understanding Vítoria's objectives. To Pagden, Vítoria and his successors: ${ }^{74}$

... were far less concerned with the particulars of the American case than they were with the

opportunities it presented for a refutation of Lutheran and later Calvinist theories of sovereignty.

A European-wide process of theological debate and confessional strife was at least as significant as were concerns about the right ways of governing the empire and the appropriate policies to be pursued in the Americas. (Even if this is correct in Vítoria's case, this line of analysis would appear to offer little, however, to the problem of understanding Las Casas' ideas and motivations: whatever else may have driven him, refuting Lutheranism and Calvinism is unlikely to have been an important priority for him.)

Vítoria and his followers were in Pagden's view less theological and legal innovators than they were conservatives, or neo-conservatives more accurately, fighting a rearguard action in defence of traditional scholarly technique against 15 th century heresy and the new theology of Erasmus, Luther and Calvin. Many historians would agree. Garrett Mattingly, a prominent historian of AngloSpanish relations in the 16th century, was unable to see anything innovative in the writings of Vítoria and others of the Spanish school, given that "most of the conclusions at which the Spanish

74 Anthony Pagden Spanish Imperialism and the Political Imagination (Yale University Press, New Haven, 1990) at 18 [Spanish Imperialism]. 
school arrived are obviously implicit in twelfth-century canonists with explicit elaborations in the fourteenth and fifteenth centuries". ${ }^{75}$ Vítoria wrote and thought against a background of "accepted ethical principles", those which had formed the basis of the teaching of philosophy and theology in the European universities for centuries, "and this", as Mattingly emphasises, "at a time when the moral consensus of Europe was less secure than it had been for centuries, and was being weakened further by the passage of every decade". ${ }^{76}$ The Reformation was in many ways a direct assault on the entire intellectual edifice to which Vítoria and scores of other academics belonged. ${ }^{77}$

From this theological, or confessional, perspective the key issue was neither international law nor the rights of the Indians, but rather the complex problem of the relationship between property rights, sin and divine grace. The issue had arisen most sharply with the teachings of the English theologian John Wycliff and the Czech Jan Hus, who had taught that the property rights and jurisdiction of those living in a state of mortal sin were forfeit. Wycliff was concerned particularly with the position of members of the clergy, and especially with the issue of the validity of the sacraments. The point may seem to be of minor importance, but in fact the implications were explosive. If Wycliff was right, sinful bishops not in a state of divine grace could not, for instance, validly ordain priests, which might mean that many priests were not truly such. Moreover, the argument touched on the rights of kings and princes. If they had for their sins forfeited God's grace then they had lost dominium over their kingdoms and could be lawfully deposed by their subjects, a radical proposition indeed. For these and other reasons, the teachings of Hus and Wycliff had been condemned as heretical and Hus was condemned and burned as a heretic at the Council of Constance in 1415. But aspects of Wycliff's and Hus' teachings had now been giving a new lease of life as a result of the preaching and writing of Martin Luther and the outbreak of the Reformation in northern Europe. There are those who see this context as decisive in explaining Vítoria's teachings. According to Pagden: ${ }^{78}$

75 Garrett Mattingly Renaissance Diplomacy (Jonathan Cape, London, 1955) at 270. Mattingly was a prominent historian of Anglo-Spanish relations in the 16th century and the author of a biography of Catherine of Aragon. His conclusions on Vítoria are not dissimilar from Robert Williams, ibid:

Though [Vítoria] demolished the customary claims of Castile to its American empire with ruthless logic, and spoke up for the natural rights of the Indians as eloquently as Las Casas, in the end he conceded enough rights to the Spanish crown to enable it to do about what it was doing.

76 Ibid, at 278 .

77 See generally Peter Harrison "Philosophy and the crisis of religion" in James Hankins (ed) The Cambridge Companion to Renaissance Philosophy (Cambridge University Press, Cambridge, 2007) 234.

78 Pagden Spanish Imperialism, above n 74, at 18. See also Anthony Pagden "Dispossessing the Barbarian: The Language of Spanish Thomism and the Debate over the Property Rights of the American Indians" in Anthony Pagden (ed) The Languages of Political Theory in Early Modern Europe (Cambridge University Press, Cambridge, 1987) 79. 
It was central to Vítoria's whole project to refute the claim of these 'modern heretics' [Luther and the other Protestants] that the authority of a prince depended not upon God's laws but upon God's grace, and the subsequent argument that if any prince fell from grace he might legitimately be deposed by his subjects or by another more godly ruler.

This, arguably, is why Vítoria goes out of his way to insist that notwithstanding the fact that the Indians of the New World were not Christians and were living in a state of sin, that did not mean that they lacked dominium over their lands and goods. ${ }^{79}$ In maintaining this point, Vítoria had at least one eye on the theological debates over mortal sin and property rights that had been raging throughout the 15 th century and on into the time of the Reformation.

Other scholars have examined Vítoria's relationship with the 15th century conciliar movement, the great political movement within the 15 th century Church which challenged the papal monarchy and sought to have the supreme government of the Church placed in the hands of a general council. ${ }^{80}$ A further issue was, supposing that ultimate authority over the Church does ultimately lie in a general council, who exactly does such a Council represent: the bishops, the entire clergy (regular and secular), or perhaps even the entire community of the faithful? There is a dismayingly large literature on this subject too. ${ }^{81}$ Vítoria's relationship with conciliarism has been examined in

79 Vítoria, Pagden and Lawrance, above n 8, at 244-245. Vítoria notes that:

Aquinas shows that unbelief does not cancel either natural or human law, but all forms of dominion (dominia) derive from natural or human law; therefore they cannot be annulled by lack of faith.

He goes on to argue that Jews or Moslems could not lawfully be deprived of their property merely because they were not Christians, and even heretics only lost their property upon conviction for the crime of heresy and not beforehand.

80 On conciliarism, see Hubert Jedin A History of the Council of Trent: The Fight for a Council (Thomas Nelson and Sons, Edinburgh, 1957 (original German edition Herder \& Co GmbH, Freiburg in Breisgau, 1949)) vol 1 at chs 1-7; a good short overview may be found in Charles Stinger The Renaissance in Rome (Indiana University Press, Bloomington, 1985) at 158-166. In 1417, the Council of Constance issued the decree Frequens which stipulated the regular convening of councils as a fundamental element of the government of the Church. The popes, however, most of whom were Italian (conciliarism was strongest in France) were opposed to subordinating themselves to councils, as might be expected. In the course of the 15 th century a revived papal monarchy defeated its conciliarist opponents and went on to ever greater heights in terms of its own self-image, Rome becoming the leading cultural centre of Italy. However, says Stinger: "rankling disenchantment with the papacy deepened, especially north of the Alps, and the gulf between Rome and the rest of Latin Christendom widened" (ibid, at 160).

81 For a brief and up-to-date survey, see Antony Black "Popes and Councils" in Christopher Allmand (ed) New Cambridge Medieval History (Cambridge University Press, Cambridge, 1998) vol 7 65; in addition to the references in the preceding footnote, see also Antony Black Monarchy and Community: Political Ideas in the Later Conciliar Controversy (Cambridge University Press, Cambridge, 1970); Antony Black Council and Commune: The Conciliar Movement and the Fifteenth-Century Heritage (Burns \& Oates, London, 1979); Antony Black "Community: The conciliar movement" in J H Burns (ed) The Cambridge History of Medieval Political Thought (Cambridge University Press, Cambridge, 1988) 573; J Gill The Council of Florence (Cambridge University Press, Cambridge, 1959); Francis Oakley The Conciliarist Tradition: 
an important article by Katherine Elliot van Liere. ${ }^{82}$ Vítoria studied at the University of Paris, a centre of conciliarist ideas, ${ }^{83}$ and of course in De Indis he challenged the papal grants of 1493 . These facts might indicate that Vítoria had conciliarist leanings, but in fact van Liere doubts this. The Dominican order, to which Vítoria and Las Casas both belonged, was opposed to conciliarism and backed the papacy. Van Liere argues that Vítoria's lectures "show that he was profoundly suspicious of conciliarism" and in fact "the main thrust of his lectures on ecclesiastical power was a systematic refutation of the conciliar theory". ${ }^{84}$ Whatever the reasons for his attack on the 1493 grants, this cannot be explained, van Liere believes, by a support for conciliarism against the jurisdictional claims of the papacy. If van Liere is correct, it appears that a closer attention to the context of the great debate over the constitutional structure of the Church yields no particular insights into explaining what Vítoria was trying to achieve. Yet, certain facts remain: Vítoria studied in Paris, a centre of conciliarist ideology, and he shows in his writings that he was certainly opposed, for whatever reason, to the wider formulations of papal universal jurisdiction. Reading papal jurisdictional claims narrowly does not of itself point to conciliarist leanings. Nevertheless, setting Vítoria's ideas in the context of the rival papal and conciliarist claims might still yield some valuable insights.

\section{COMPLICATING THE STORY: NEW HISTORIOGRAPHIES OF EMPIRE}

Historians now emphasise that indigenous peoples did not stand idly by, give up or become passive objects in the face of European expansion in the Americas, Asia and the Pacific; they resisted, temporised, changed, adapted, tried to exploit the European presence to get even with tribal enemies, adopted Christianity and in some ways made it their own, changed their material culture, and even defined and invented or reinvented themselves. Or, indeed, they may not even have seen the European presence as all that interesting or significant, or would have interpreted it very much through their own frames of reference. Of particular importance in the context of colonial Latin American historiography is a group of United States scholars, who can be called - not altogether accurately - the "Lockhart school" (sometimes referred to as the "New Philology"), exemplified in

Constitutionalism in the Catholic Church 1300-1870 (Oxford University Press, Oxford, 2003); Brian Tierney Foundations of the Conciliar Theory: The Contributions of the Medieval Canonists from Gratian to the Great Schism (Cambridge University Press, Cambridge, 1957).

82 See generally Katherine Elliott van Liere "Vitoria, Cajetan and the Conciliarists" (1997) 58 JHI 597 and references therein cited.

83 A great bastion of the conciliar viewpoint was the Faculty of Theology at the University of Paris, which regarded itself as no less a guardian and bastion of Catholic orthodoxy than the papacy itself. As Jedin writes (above n 80, at 32): "Gallican France was the real stronghold of the strict conciliar theory and the University of Paris its citadel"; "ruthless treatment was meted out to any scholar who presumed to tamper with it".

84 Van Liere, above n 82, at 601. 
the work of such scholars as James Lockhart himself ${ }^{85}$ as well as Sarah Cline, ${ }^{86}$ Rebecca Horn, ${ }^{87}$ Matthew Restall ${ }^{88}$ and Kevin Terraciano. ${ }^{89}$ This new scholarship, especially as developed by such sophisticated practitioners as Lockhart, has now evolved far beyond questions of adaptation and resistance to focus on much more subtle changes in world view and perception, an emphasis which demands very considerable linguistic skills on the part of the historian. Lockhart and his colleagues have ventured into new fields of historical inquiry where no historians of colonial New Zealand or Australia have - so far - followed them. While this might be a difficult project in the case of Australia, this is not the case with New Zealand, which - like Latin America - is fortunate to possess a vast corpus of materials written in the indigenous language using the Latin script taught originally by the missionaries (members of the Catholic regular orders in the Latin American case, mostly evangelical Anglican protestants in New Zealand). Whether, however, the particular approach of the Lockhart school to colonial and indigenous interactions has led to real gains in understanding is an open question. They have certainly pushed studies of colonial Latin America in the United States very markedly in a linguistic and textualist direction, but it also appears that some fissures are now beginning to emerge between scholars who are interested in exploring indigenous texts in detail for their own sake and those who are exploring the extent to which language and grammar were themselves techniques of control and oppression. ${ }^{90}$

85 See especially James Lockhart The Nahuas After the Conquest: A Social and Cultural History of the Indians of Central Mexico, Sixteenth Through Eighteenth Centuries (Stanford University Press, Stanford, 1992); James Lockhart "Sightings: Initial Nahua Reactions to Spanish Culture" in Stuart B Schwartz (ed) Implicit Understandings: Observing, Reporting and Reflecting on the Encounters between Europeans and Other Peoples in the Early Modern Era (Cambridge University Press, Cambridge, 1994) 218; James Lockhart Of Things of the Indies: Essays Old and New in Early Latin American History (Stanford University Press, Stanford, 1999) [Of Things of the Indies]. Perhaps the "Lockhart school" could also be called the "Stanford" school as most of their writings appear under the prestigious imprint of Stanford University Press.

86 See Sarah L Cline Colonial Culhuacan 1580-1600: A Social History of an Aztec Town (University of New Mexico Press, Albuquerque, 1986); Sarah L Cline "The Spiritual Conquest Reexamined: Baptism and Christian Marriage in Early Sixteenth-Century Mexico" (1993) 73 Hispanic American Historical Review 453: Sarah L Cline "Native Peoples of Colonial Central Mexico" in Richard EW Adams and Murdo J MacLeod (eds) The Cambridge History of the Native Peoples of the Americas (Cambridge University Press, Cambridge, 2000) 287.

87 Rebecca Horn Postconquest Coyoacan: Nahua-Spanish Relations in Central Mexico, 1519-1650 (Stanford University Press, Stanford, 1997).

88 Matthew Restall The Maya World: Yucatec Culture and Society, 1550-1850 (Stanford University Press, Stanford, 1997); Matthew Restall Maya Conquistador (Beacon Press, Boston, 1998); Matthew Restall Seven Myths of the Spanish Conquest (Oxford University Press, New York, 2003) [Seven Myths].

89 Kevin Terraciano The Mixtecs of Colonial Oaxaca: Nudzahui History, Sixteenth through Eighteenth Centuries (Stanford University Press, Stanford, 2001).

90 There has been a flood of recent, often lavishly illustrated, close analyses of the various principal Mexican and Guatemalan indigenous manuscripts and codices - indeed by now there must be one or more monographs per document. What such a vast investment of meticulous intellectual effort actually achieves 
The Spanish jurists are a powerful presence in the work of Lockhart and others by their complete absence. In their studies of the cultural and social transformation of the indigenous peoples of the Americas the historians of the Lockhart school simply ignore Vítoria and Las Casas. ${ }^{91}$ In fact, they ignore ideologies of empire and meta-legal frameworks completely, an eloquent silence indeed. Theological and legal debates at the imperial centre are of no significance to a scholarly enterprise that by definition is concerned with local realities and with local documents written in the indigenous languages, but even so the non-appearance of the Spanish jurists seems very pointed, the product of a quite deliberate redirection of emphasis. The approach is essentially to go a step beyond historians such as Henry Kamen, who questions the relevance of scholarly debate to imperial practice; instead, the focus is entirely on local communities and documents in the Native languages. ${ }^{92}$ Obviously, these scholars are writing a different kind of history, but it is after all a history which claims to be one that is much closer to indigenous realities. The implicit suggestion is that to Maya people in the Yucatan, Nahua people in the Valley of Mexico, or Mixtec people in Oaxaca, the process of dispute and debate in Spain counted for nothing, either in terms of how they were actually governed or - more importantly - what mattered to them. To believe in the importance of Vítoria and Las Casas is to believe in the importance of royal policy, but in fact this is itself disputed. To one scholar the view that royal policies were "the primary instigators of social and economic change in the colony [Mexico]" is simply "dated"..$^{93}$ (If this observation was transferred to a New Zealand context, I would say that if it is "dated" to believe that Crown policies were the "primary instigators of social and economic change" in Aotearoa it is, nevertheless, true.)

is not clear. For a linguistic study which goes into new territory to inquire into the extent to which the systematisation of the Maya language by the Franciscan order in the Yucatan facilitated the colonisation of the Yucatec Maya people, see William F Hanks Converting Words: Maya in the Age of the Cross (University of California Press, Berkeley, 2010). This book is part of a series of innovative studies on the "anthropology of Christianity". There may be scope for a similar work on the systematisation of Māori by the missionaries of the Church Missionary Society in 19th century New Zealand.

91 Las Casas and Vítoria are missing from the indexes of Lockhart's Nahuas after the Conquest, Restall's Maya World and Terraciano's Mixtecs of Colonial Oaxaca (I admit I have had not checked all the works of the Lockhart school). This is not meant as a criticism in itself of course, but it does demonstrate clearly what these historians see as important and what they do not. For useful historiographical discussions, see Stephen Haber "Anything Goes: Mexico's 'New' Cultural History" (1999) 79 Hispanic American Historical Review 307; John E Kicza "Recent books on Ethnohistory and Ethnic Relations in Colonial Mexico" (1995) 30 Latin American Research Review 239; John E Kicza "New Interpretations of Colonial Mexico from the Conquest to Independence" (2005) 40 Latin American Research Review 326 ["New Interpretations"]; Cynthia Radding "Cultural Dialogues: Recent Trends in Mesoamerican Ethnohistory" (1998) 33 Latin American Research Review 193; Matthew Restall "A History of the New Philology and the New Philology in History" (2003) 38 Latin American Research Review 113; Susan Migden Socolow "Putting the 'Cult' in Culture" (1999) 79 Hispanic American Historical Review 355; Eric Van Young "The New Cultural History comes to Old Mexico" (1999) 79 Hispanic American Historical Review 211.

92 See Kamen, above n 7, at 472 .

93 Kicza "New Interpretations", above n 91, at 333 (which is surely to go much too far). 
Tenurial and agrarian change in Mexico, it is argued, developed autonomously rather than in response to royal policies and orders: in Lockhart's words, "The royal policy of discouraging an independent aristocracy and the humanitarian campaigns to protect the Indians deserve intensive study in themselves", however, "the struggles over these matters cannot be said to greatly affected the evolution of the great estate" - the latter being the most decisive process in rural New Spain as far as Lockhart is concerned. ${ }^{94}$ That perhaps the most important and innovative school of historians working on cultural and social change in the Spanish colonial empire sees the process of debate and polemic in Spain as essentially irrelevant is indeed a sobering thought.

Lockhart and other like-minded scholars are certainly interested in law and legal texts, but they have switched focus from royal commands and ordinances emanating from Spain - the very forms of law-making most likely to be influenced by scholars like Vítoria and polemicists such as Las Casas - to legal documents produced in the Indies: wills, contracts and notarial documents written in Nahuatl, Yucatec Maya, Mixtec and other indigenous languages. Such legal texts are seen as the ones that really matter: royal ordinances were ignored or subverted as much as they were enforced. Legal historians would find the approach of the Lockhart school puzzling; at least, it takes some getting used to. To put their style of legal history into a New Zealand context, a similar approach would be to ignore completely the intellectual framework of Native title, the statutes relating to land titles and confiscation, and the case law of the courts and the Native Land Court, and to focus instead on the grammar and conceptual language of wills, contracts, petitions and other legal texts written in the Māori language - of which, as it happens, there is no shortage. In fact, there is probably much more to work with in the case of Māori, which has now been a written language for nearly two centuries, than with Mixtec, Nahuatl or Yucatec Maya. It becomes easy to see, I would argue, that while such an approach - which no one has yet embarked on with respect to Māorilanguage legal sources, given that the basic linguistic work is only now finally being done ${ }^{95}$ - could certainly yield some fascinating insights, it could not amount to a complete account of the Māori engagement with law. (Nevertheless a Lockhart-style book on Māori legal texts would be a very welcome event.)

The linguistic turn in United States scholarship has been accompanied by some more precisely historiographical perspectives. ${ }^{96}$ Lockhart and his school stress that much Spanish colonisation of

94 Lockhart Of Things of the Indies, above n 85, at 23.

95 As the result of a major linguistic project on Māori legal texts coordinated by Mamari Stephens of the School of Law at Victoria University of Wellington. This is one of the most important and challenging research exercises currently underway in New Zealand. The research has involved the scrutiny of thousands of documents and the compilation of a linguistic database; this will be followed in turn by a Māori legal language dictionary and then, no doubt, by some very interesting work on Māori and law along the lines developed by Lockhart, Restall, Cline, Terraciano and others.

96 See especially Restall Seven Myths, above n 88. 
the New World was not carried out by the Spanish State, still less by the Spanish army, but by private enterprise operating under Crown licence. Conquistadores were motivated principally by the desire to make a profit: colonisation was not a search for adventure, souls and glory but in fact a form of business enterprise based on credit. ${ }^{97}$ They also stress the undeniable fact, which has long been noted by historians, that indigenous support was vital to Spanish military success in Mexico and Peru. ${ }^{98}$ Given these realities, arguably much of the more starry-eyed mythologizing about the Spanish school and the Spanish "search for justice" simply dissolves. Vítoria's lectures or Las Casas' great debate with Sepúlveda in 1550 had no impact on contemporary reality; in fact, colonial expansion was not actually controlled by the Crown, at least in its earliest phases, and even after 16th century economic and social developments, such as the decline of the encomienda (tribute grant) and the rise of the hacienda, great estates owned outright by the creole nobility, were little affected by royal laws and royal policies. What can be said of a Spanish struggle for justice in the conquest of the New World when much of that very conquest was carried out by indigenous allies? In the course of the 16th century the Crown, after a long struggle, managed to assert its authority in the New World, but whether this was actually to the advantage of the indigenous populations in any way is something many historians doubt. Certainly, there is no reason to believe that the story was a simple one of a struggle between rapacious conquistadores and a benevolent Crown anxious to protect the welfare of its Indian subjects and to put the humane precepts of Vítoria and Las Casas into effect. To Lockhart, "the crown knew and cared far less about the amorphous society of the Indies than about the administrators it appointed or the export economy that produced its revenues". ${ }^{99}$ The point is not simply that the Crown was able to assert its authority only with some difficulty in the colonies, but that in fact the Spanish government at the end of the day was far more about the flow of silver bullion across the Atlantic than about the well-being of the Indians.

Spanish, Portuguese, Spanish-American and Brazilian historiography is far too rich to be engaged with here. Key Latin American countries such as Mexico, Costa Rica, Colombia and Brazil have of course developed elaborate historiographies of their own, historiographies which are of far

97 For a brilliant and fascinating study of Spanish colonial undertakings as a form of family business activity, see Rafael Varón Gabai's study of the Pizarro family in Peru: Rafael Varón Gabai Francisco Pizarro and his Brothers: The Illusion of Power in Sixteenth-Century Peru (University of Oklahoma Press, Norman, 1997). The Montejos, father, son, and nephew, who undertook the conquest of the Yucatan under royal licence are another example.

98 See for example Restall Seven Myths, above n 88, at 44-63. The same can be said of New Zealand: the New Zealand wars of the 1860 s were also Māori civil wars. At the battle of Omarunui near Napier in 1866, there were more Māori fighting on the side of the New Zealand government than on the "Māori" side. The larger significance of this dimension of colonisation is more complicated than it seems, however, and I will not pursue it further here.

99 Lockhart Of Things of the Indies, above n 85, at 35. 
more than local or regional importance. ${ }^{100}$ The more purely linguistic and textualist approach of the Lockhart school does not seem to have significantly impacted on Latin American historical writing, insofar as far as I am in a position to tell, which continues to develop its solid focus on basic questions of structural economic and social change during the colonial period. Las Casas continues to be seen as a key figure. Aspects of French historical writing, especially the Annales school as exemplified by the work of Lucien Febvre, Marc Bloch and Fernand Braudel, has been influential in some Latin American countries, especially Mexico. Latin American scholarship often turns to France as a way of escaping from the intellectual hegemony of the Anglo-Saxon colossus of the North. Again, this historiography cannot be reviewed comprehensively here, save to note briefly aspects of French scholarship that seem distinctive when compared to Anglo-American writing. French scholarship has always been closely interested in Latin America, as shown by the work of such celebrated intellectuals as Jaques Soustelle and Claude Lévi-Strauss, ${ }^{101}$ and French intellectual and cultural traditions and styles have also been highly influential in key Latin American countries such as Mexico and Brazil. A key recent French contribution is the work of Carmen Bernand and Serge Gruzinski, authors of a new multi-volume history of the colonial Americas (regrettably, not so far translated into English). ${ }^{102}$ As critical historians of globalisation, they write of the colonial Americas as a precursor of contemporary globalised modernity - as a vast zone of cultural mixing and the creation of new identities, often achieved with great brutality and destructiveness, but also full of surprising complexities and juxtapositions. With their focus on an occidental globalisation, to them the key date is not 1492 but 1519, when Charles V became emperor, Magellan set out on the

100 For guides to Latin American historiographies, see for example Enrique Florescano Historia de las historias de la nación mexicana (Taurus, México, 2002) (English translation by Nancy T Hancock National Narratives in Mexico: A History (University of Oklahoma Press, Norman, 2006)). See also above n 32.

101 See for example Jacques Soustelle La Vie quotidienne des Aztèques à la veille de la conquête espagnole (Hachette, Paris, 1955) (translated as The Daily Life of the Aztecs (Penguin Books, Harmondsworth, 1964)). Soustelle was a prominent French intellectual, Governor-General in Algeria (1955-1956), Minister of Information under De Gaulle and a director of the Musée de l'Homme; as for Lévi-Strauss, his Tristes Tropiques (Librairie Plon, Paris, 1955) is largely based on his experiences in Brazil. France has also produced some of the principal historians of 16th century Spain and Spanish colonial expansion, including Pierre Chaunu and Marcel Bataillon.

102 Carmen Bernand and Serge Gruzinski Histoire du Nouveau Monde (Librairie Arthème Fayard, Paris, 1991) 2 vols. Of particular importance here is the first volume, De la découverte à la conquête, une expérience européene, 1492-1550 (Librairie Arthème Fayard, Paris, 1991) (Spanish translation by María Antonia Neira Bigorra Historia del Nuevo Mundo, Tomo I: Del Descubrimiento a la Conquista: La experiencia europea (Fondo de Cultura Económica, México, 1996). References here are to the Spanish translation, the French original being unavailable to me). 
first circumnavigation of the world and Cortés sailed from Cuba to Mexico, the first step in the encounter between Europe and the high civilisations of the Americas: ${ }^{103}$

$\ldots$ it is the story of the first step in the westernization of America and the prefiguration of a phenomenon

which today one can see on a planetary scale: the uniformity of the world arising from a double process

of the destruction of tradition and the diffusion of values, institutions and ways of life produced by and

spread everywhere from western Europe.

They argue that a narrow focus on the leyenda negra is an obstacle to coming to terms with the vast and complex reality of Spanish and Portuguese America, which of course not only has a far longer history than that of the United States, but which was a prime creator of modernity. ${ }^{104}$ Unlike Lockhart and his school, Bernand and Gruzinski pay a great deal of attention to developments in Spain itself, but mainly to show how Spanish patterns of government and political clientage reproduced themselves on a hemispheric scale in Mexico and Peru. Latin America was a hemispheric projection of Mediterranean Europe, just as North America later became a projection of North Atlantic Europe. They discuss Las Casas as essentially a man of two worlds, who moved back and forth between the Indies and Spain, a kind of exemplar of the first phase of globalisation, but have little to say about Vítoria.

Gruzinski is also the author of a number of other key books which focus in a very original manner on the use of images and texts in the Spanish American colonies. ${ }^{105}$ Characteristically, he sees the use of images as a vital aspect of the westernisation and globalisation of the world - his book on The War of the Images has the fictional end-point of 2019 and the dystopia of Ridley Scott's Blade Runner, the apotheosis of a degraded and brutalised globalisation of the image. Another important French scholar is Christian Duverger, author of key books on Mesoamerican archaeology, colonial Mexican art history and of a remarkable new biography of Cortés which sees him as a would-be pioneer of a new mestizo Mexico - something which he (Cortés) was committed to both intellectually and in the way he lived his own life. French scholarship focuses on a particular vision of world history that seems distinct from that of the Anglo-Saxon world, and focuses on

103 Bernand and Gruzinksi, ibid, at 255:

Se trata de la primera etapa de la occidentalización de América y la prefiguración de un fenómeno que hoy puede observarse in escala planetaria la uniformidad del mundo en su doble movimiento de destrucción de la tradición y de diffusion de los valores, las instituciones y los modos de vida que ha producido y esparcido la Europa occidental.

104 Ibid, at 10 .

105 Serge Gruzinski La colonisation de l'imaginaire: Occidentalisation et sociétés indigènes dans le Mexique espagnol (Gallimard, Paris, 1988); Serge Gruzinski La guerre des images: de Christophe Colomb à "Blade Runner" (1492-2019) (Librairie Arthème Fayard, Paris, 1990) (Spanish translation by Juan José Utrilla La guerra de los imágenes: De Cristóbal Colón a "Blade Runner" (1492-2019) (Fondo de Cultura Económica, México, 1994)). 
cultural interchange and on the emergence of a globalised world, a world which French scholars are, however, extremely ambivalent about. Perhaps it is this very ambivalence that gives French historical writing its most distinctive note, although the willingness to engage directly with difficult and painful transitions also is different from much historical writing produced in the Englishspeaking world which - to me, at least - all too often seems narrow and provincial by contrast.

\section{CONCLUSIONS AND LOCAL RESONANCES}

There are thus many Vítorias. Those highlighted here are Vítoria the founder of human rights theory, Vítoria the protector of the Indians, Vítoria the imperialist and Vítoria the theologian. And there are several Las Casas as well: Las Casas the apostle of America, the defender of the Indians, the obsessed mentally unstable paranoiac and unpatriotic founder of the leyenda negra (a view receding from memory, seemingly), and even Las Casas the imperialist. Some historians of the Spanish empire see them both as important, some ignore them completely as irrelevant, others again see one as more important than the other; some see their legacy as positive and benign, something to celebrate, others as part of an edifice which needs to be deconstructed, if not blown to pieces. Seeing either of them steadily and whole is no easy matter. I will not attempt to do so here. All I have tried to convey is the sheer complexity and variety of the historiography within which both are entangled.

In view of the foregoing, it might well be wondered whether it is still possible to see Vítoria and Las Casas - and their successors - in any straightforward way as champions of the human rights of the indigenous peoples of the Americas. But this is indeed still possible, as a recent article shows. Gonzalo Lamana has argued that a close examination of the context of Vítoria's De Indis is a clue to what he was attempting to achieve. ${ }^{106}$ Vítoria delivered the lectures on which De Indis is based "when the conquerors were still fighting Inca resistance" in Peru ${ }^{107}$ - a context which, it is implied, Vítoria and his audience would certainly have known about. In particular, Vítoria's lectures can be seen as a clear attack on, and response to, a tract published by Francisco Xeréz, Pizarro's secretary. His account, Verdadera relación de la conquista del Perú (True narrative of the conquest of Peru) was an attempt at justifying the murder of the Inca sovereign Atahualpa and the conquest of the Inca State, and it went through a number of editions in Spain. ${ }^{108}$ There were a number of other, similar accounts. Vítoria responds to their arguments, it can be seen, point by point. Las Casas, for his part, was especially scathing about the justifications advanced by the Pizarro family and their supporters for what had happened in Peru. Lamana notes that Las Casas' Brevisima relación "is what its title suggests ... a hammering narrative of the acts of the Spanish conquerors in which they are portrayed

106 Gonzalo Lamana "Of Books, Popes and Huacas: or, The Dilemmas of being Christian" in Greer, Mignolo and Quilligan, above n 19, at ch 7.

107 Ibid, at 124

108 Ibid, at 119. According to Lamana, Xérez' Verdadera relació "was a success, and not just in Spain: two Italian translations appeared in 1535, it was reprinted four times in Spain in 1540 and three times in 1547, and it was reprinted once in Italy in 1556": ibid. 
as monsters". ${ }^{109}$ Lamana does not doubt, nevertheless, that Las Casas was certainly committed to Spanish imperialism - but what he does reveal, I suggest, is the intensity and genuineness of argument and debate in Spain, even if it was contained within a framework which accepted and endorsed Spanish expansionism. The debate was real - a "struggle for justice" indeed, even if it was "based on the unquestionable superiority of Christianity and its symbols". ${ }^{110}$ Lamana has also shown that a close attention to context can still yield new insights about what Vítoria and Las Casas were seeking to achieve.

How to bring a virtually limitless debate to some kind of even interim resolution is not easy to see. This article is written (obviously) by an antipodean scholar, and my interests are less with discovering the supposed doctrinal origins of the structure of indigenous people's law or human rights law - a misconceived project, in my view, as I am not at all certain that there is a coherent structure to uncover and analyse - as with the historiographical problem of the links between legal doctrine and actual events and processes on the colonial frontiers. Whether to celebrate or denigrate Vítoria and Las Casas seems in the end less interesting than seeking to uncover the relationships between the formation of law and policy at the imperial centre and the realities of what happened in the Andes, in New Spain, or in more local zones of interaction such as the Yucatan, Oaxaca or the southern frontiers of Chile - or, indeed, switching to the context of the 19th century British empire, in the South Waikato or Hawke's Bay or Queensland. Taking this as the real issue - itself debatable of course, then some of the discourses described above grapple with it much more successfully than others. Robert Williams, James Brown Scott, Felix Cohen and Lewis Hanke, for all their differences of emphasis and approach, all take it for granted that the legal and theoretical debates that took place in 16th century Spain mattered profoundly, at the time, as well as for posterity. Posterity may, of course, decide to embark on a project of remodelling international human rights theory by seeking to construct it on naturalist rather than positivist foundations, by no means an illegitimate enterprise, and which may even - less clearly - allow Vítoria and his colleagues to be brought into the argument, provided that the presentist and ahistorical nature of the enterprise is clearly recognised. That particular undertaking, however, seems to be altogether separate from the historiographical issues I am concerned with. Did the process of debate and law-making in Spain really matter particularly at the time? Did it lead to real outcomes and did it actually ameliorate Spanish imperialism in any significant way? Did it really have much of an impact on colonial realities? The reader will probably have worked out by now that I do not really think so.

On the other hand, the approach of the neo-philological school of Lockhart, Restall, Terraciano and others can sometimes go too far in the other direction of ignoring the evolving structures of law and policy entirely - save to the extent that documents such as wills and contracts can be analysed as stand-alone texts which, when read carefully, can provide important data about social history and

109 Ibid, at 125.

$110 \mathrm{Ibid}$, at 127. 
social change. ${ }^{111}$ The approach of the Lockhart school only works within a historiographical setting in which issues of law, policy and practice have already been debated and dissected in a vast literature - which is not yet the case with New Zealand and Pacific history. The Latin American neo-philologists are looking for something new to say within a framework of a rich and developed historiography with which its antipodean counterpart can hardly compare (so far). Also, while it may be the case that Vítoria wrote and thought within a context in which theological debates over grace and the sacraments were a central concern, it has not been shown that this is the only matter that Vítoria was concerned about or even that it was his prime or principal concern. He did choose to focus specifically on the legal problems caused by the conquest and settlement of the Indies, and De Indis is quite clearly about the justice of Spain's claim to legal title there. In any case, what may go for Vítoria cannot go for Las Casas. Las Casas, whether one agrees or disagrees with him, was notwithstanding Daniel Castro - beyond any doubt the genuine article, a real activist centrally and fundamentally concerned with the rights of the Indians. Probably, writers such as Bernand and Gruzinski and Henry Kamen, who stress the multinational and multicultural dimensions of the "Spanish" empire, and Bernand and Gruzinski's focus on the different ways in which mestizaje cultural and biological intermixing - played out on a range of diverse colonial frontiers, get closest to the complicated reality of things. But even a work of the vast scale and complexity of Bernand and Gruzinski's magnum opus does not explain everything. Their somewhat cinematic, indeed sometimes hallucinatory treatment of events does not always clarify the relationships between policy and practice: they are more interested in the practice, in the richness and diversity of colonial interactions, than in the legal and policy frameworks which undergirded it all, and which are certainly important even if they were often subverted on the ground by colonial realities.

Who has come closest to getting it right, as it were, is perhaps a naive approach in itself, and is certainly something that no consensus can be arrived on. What is more important and interesting from a Pacific history perspective is that exactly the same questions arise with the relationship between law and practice and between centre and periphery on New Zealand and Pacific colonial frontiers as they do in New Spain and Peru. The point can be illustrated by the fate of Māori land confiscation in the North Island in the 19th century. One can look for the doctrinal sources of confiscation law and policy, and indeed find them to a certain extent in 17th century Ireland and also in the Cape Colony and Natal in the 19th century. Also, there certainly was a debate about the justice of confiscation in New Zealand in Britain and in the House of Commons - far more so than there was in New Zealand itself, as it happens. Perhaps it might be possible to write a book entitled The British Struggle for Justice in the British Colonial Empire in the Nineteenth Century, which could be richly illustrated by material relating, say, to New Zealand, the West Indies and the South African colonies. In fact, although such a book remains to be written, it would perhaps be much more plausible than Hanke's claim that there was a Spanish "struggle for justice" in the 16th

111 See Lockhart Of Things of the Indies, above n 85, at 229-280. 
century. ${ }^{112}$ Such was evangelical enthusiasm in England for doing good to the indigenous peoples of the empire that Charles Dickens was able to pay it the compliment of merciless satire, most memorably in the characters of Mrs Jellyby and Mrs Pardiggle in Bleak House. ${ }^{113}$ (Mrs Jellyby, who "could see nothing nearer than Africa", is absorbed in a project to promote coffee-growing and British settlement for the benefit of the Natives of Borioboola-Gha "on the left bank of the Niger", ${ }^{114}$ while her own children are neglected and her household is in chaos; Mrs Pardiggle, of similar leanings, forces her resentful children to subscribe their pocket money for various good causes, including that of the "Tockahoopo Indians". ${ }^{115}$ ) But as the example of land confiscation readily shows, any monograph on Britain's "struggle for justice" would be incomplete without any consideration of the actual realities of land confiscation as it was applied on the New Zealand or South African colonial frontiers. ${ }^{116}$ Balancing law and policy at the centre, and the realities of

112 In the 16th century, Spain lacked any counterpart to such mass political movements such as anti-slavery in Britain (on which the literature is much too extensive to cite here). I am not aware of any recent full scale general treatment of the process of public debate on the rights of indigenous peoples in the British empire. See, however, Alan Lester "Humanitarians and White Settlers in the Nineteenth Century" in Norman Etherington (ed) Missions and Empire (Oxford University Press, 2005) at ch 4. For aspects of the debate or case studies, see for example Jean Comaroff and John L Comaroff Of Revelation and Revolution: Christianity, Colonialism, and Consciousness in South Africa (University of Chicago Press, Chicago, 1991); Jeffrey Cox, The British Missionary Enterprise (Routledge, New York, 2010); Julie Evans, Patricia Grimshaw, David Philips and Shurlee Swain Equal Subjects, Unequal Rights: Indigenous Peoples in British Settler Colonies, 1830s-1910 (Manchester University Press, Manchester, 2003); John Gascoigne The Enlightenment and the Origins of European Australia (Cambridge University Press, Cambridge, 2002); Catherine Hall Civilizing Subjects: Metropole and Colony in the English Imagination, 1830-1886 (Cambridge University Press, Cambridge, 2002); Mark Hickford "'Decidedly the Most Interesting Savages on the Globe': An approach to the intellectual history of Māori property rights, 1837-1853" (2006) 27 History of Political Thought 122; Paul McHugh Aboriginal Societies and the Common Law (Oxford University Press, Oxford, 2004); JG Pretorius The British Humanitarians and the Eastern Cape Frontier, 1834-1836 (Government Printer, Pretoria, 1988); Richard Price Making Empire: Colonial Encounters and the Creation of Imperial Rule in Nineteenth-Century Africa (Cambridge University Press, Cambridge, 2008); Jane Samson Imperial Benevolence: Making British Authority in the Pacific Islands (University of Hawaii Press, Honolulu, 1998).

113 Charles Dickens Bleak House (Vintage Books, London, 2008). Bleak House was first published in serialisation from 1852-1853.

114 Ibid, at 37 .

115 Ibid, at 101. After Mrs Pardiggle has listed the various worthy causes, including that of the Tockahoopo Indians, to which the children have pledged all their pocket money, the narrator (Esther Summerson) continues:

We had never seen such dissatisfied children. It was not merely that they were weazened and shrivelled - though they were certainly that too - but they looked absolutely ferocious with discontent. At the mention of the Tockahoopo Indians, I could really have supposed Egbert to be one of the most baleful members of that tribe, he gave me such a savage frown.

116 On confiscation in New Zealand, see generally Richard Boast and Richard Hill (eds) Raupatu: The Confiscation of Maori Land (Victoria University Press, Wellington, 2009); P G McHugh, Richard Boast and 
interaction and compromise, lies at the heart of colonial legal history, and it is a balance that is always likely to remain elusive.

Mark Hickford Law and Confiscation: Essays on Raupatu in New Zealand History (Treaty of Waitangi Research Unit, Stout Centre for New Zealand Studies, Victoria University of Wellington, 2010). Professor Judith Binney has recently explored the effects of confiscation on the Tuhoe people of the Urewera region of the North Island: Judith Binney Encircled Lands: Te Urewera, 1820-1921 (Bridget Williams Books, Wellington, 2010) at 100-133. 
